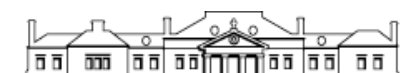

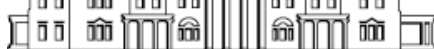

Levy Economics o

Institute

of Bard College

Working Paper No. 875

\title{
Minsky at Basel: A Global Cap to Build an Effective Postcrisis Banking Supervision Framework
}

by

\section{Giuseppe Mastromatteo}

Economic Policy Institute, Università Cattolica del Sacro Cuore

Lorenzo Esposito*

Bank of Italy, Milan

September 2016

* The views expressed are those of the author and do not involve the responsibility of the Bank of Italy.

The Levy Economics Institute Working Paper Collection presents research in progress by Levy Institute scholars and conference participants. The purpose of the series is to disseminate ideas to and elicit comments from academics and professionals.

Levy Economics Institute of Bard College, founded in 1986, is a nonprofit, nonpartisan, independently funded research organization devoted to public service. Through scholarship and economic research it generates viable, effective public policy responses to important economic problems that profoundly affect the quality of life in the United States and abroad.

Levy Economics Institute

P.O. Box 5000

Annandale-on-Hudson, NY 12504-5000

http://www.levyinstitute.org

Copyright (C) Levy Economics Institute 2016 All rights reserved

ISSN 1547-366X 


\begin{abstract}
The global financial crisis shattered the conventional wisdom about how financial markets work and how to regulate them. Authorities intervened to stop the panic-shortterm pragmatism that spoke volumes about the robustness of mainstream economics. However, their very success in taming the collapse reduced efforts to radically change the "big bank" business model and lessened the possibility of serious banking reformmeaning that a strong and possibly even bigger financial crisis is inevitable in the future. We think an overall alternative is needed and at hand: Minsky's theories on investment, financial stability, the growing weight of the financial sector, and the role of the state. Building on this legacy, it is possible to analyze which aspects of the post-2008 reforms actually work. In this respect, we argue that the only effective solution is to impose a global cap on the absolute size of banks.
\end{abstract}

Keywords: Banking Regulation; Financial Stability; Minsky; Basel 3

JEL Classifications: E12, G01, G28 


\section{INTRODUCTION ${ }^{1}$}

The financial crisis that, with ebb and flows, has been plaguing world economy since 2007 has produced many famous deaths. Among them: mainstream economic policies, including those coming from an emasculated version of Keynesian economics (the world of market imperfections); the light-touch regulation approach; the idea that more public intervention by government and central banks means inflation; and finally, the idea that concentration of income and wealth is good for growth.

However, in contrast with the Benjamin Franklin dictum, these deaths are not certain. As soon as public intervention succeeded in the taming panic, Wall Street recovered in terms of profits and the panic was quieted. This excluded the possibility of any serious reform of the financial system. This also means that a strong and possibly even bigger financial crisis is likely later on.

As an earthquake does with the terrain, the crisis helped to unearth what Keynes called the "underworld," including the ideas of Hyman P. Minsky, but soon after he followed the fate of financial reforms back into limbo. Before serious reforms and Minsky's theories are handed back to the historians of economic thought, and also before a new crisis comes to shatter the world economy, we think it is time to thoroughly assess the contributions Minsky can make to banking supervision.

We will try to show that his theories can rebuild the understanding of how modern capitalism works in terms of trends and cycles, the role of finance, the role of the state and, last but not least, how to create effective banking supervision.

This paper is structured as follows. We start with a list (the "decalogue") of what we think are the basic trends in the world financial system as a basis of what we will say about regulation. Next we analyze how the banks situate themselves in this framework in

\footnotetext{
${ }^{1}$ The authors wish to thank the participants at the 56th Annual Conference of the Società Italiana degli Economisti, in Naples (October 23, 2015), for very helpful comments on an earlier draft of this paper.
} 
terms of their business model and risks, especially systemic risk. Thirdly, we will expose the theory of investment and profits stemming from the Kaleckian tradition that can highlight the inner source of financial bubbles. With these elements we consider what has been done after the crisis in the field of banking regulation and we find that the proposals, although positive, are not able to change the landscape (i.e., the strength of big banks). Hence we reach the only viable conclusion: an absolute limit to banks' size, a proposal that we try to demonstrate has many advantages and only minor drawbacks.

\section{THE MAIN TRENDS IN THE WORLD FINANCIAL SYSTEM: A DECALOGUE ${ }^{2}$}

In the years that preceded the crisis, all the data on finance and banking confirmed the growing and positive role of big banks in the world economy, although this could not find a place into the theoretical orthodox framework. It is trivial now to note how dangerous this lack of understanding was and how the consensus has changed (Cecchetti and Kharroubi 2015). It also means that it is crucial to propose an alternative based on the main trends of the world as it is. To start, we will touch on a dozen aspects we deem the most relevant and we will show their reciprocal links. Later on this will allow us to propose a theoretical alternative.

First we start with the overall growth of the financial system that introduces us to the general picture. Among many, we make two citations:

The defining feature of financialization in the US has been an increase in the volume of debt [...] between 1973 and 2005 total debt rose from 140 to 328.6 percent of GDP. Financial sector debt also grew much faster than non-financial sector debt, so that financial sector debt rose from 9.7 to 31.5 percent of total debt over the same period. (Palley 2007)

\footnotetext{
${ }^{2}$ In this work, although not technically precise, we will use financial and banking regulation / supervision indifferently. Moreover, with "Basel II" and "Basel III" we will mean the general state of banking supervision before and after the crisis.
} 
Several decades of deregulation and innovation grossly inflated the size of financial markets relative to the real economy. The value of all financial assets in the US grew from four times GDP in 1980 to ten times GDP in 2007. In 1981 household debt was 48\% of GDP, while in 2007 it was $100 \%$. Private sector debt was $123 \%$ of GDP in 1981 and $290 \%$ by late 2008 . The financial sector has been in a leveraging frenzy: its debt rose from $22 \%$ of GDP in 1981 to $117 \%$ in late 2008 . The share of corporate profits generated in the financial sector rose from $10 \%$ in the early 1980 s to $40 \%$ in 2006 , while its share of the stock market's value grew from $6 \%$ to $23 \%$. (Crotty 2008 )

This trend was accelerating before the crisis: "In the five-year period covering 2002-2007, the ratio of debt to national income in the United States increased from 3.75:1 to 4.75:1" (Acharya et al. 2010) and has continued even after (Dobbs et al. 2015). The staggering credit and financial growth enormously outpaced the general economic growth:

For the WTO, the international transactions on goods and services increased 11 times from 1977 to 2007. During the same years financial transactions in foreign exchange markets grew at a much higher rate than international trade. They increased 175 times if we only include traditional products and 281 times if we add derivative contracts on exchanges and interest rates. (Panico et al. 2012; see also Haldane et al. 2007).

Against this general picture, there are specific important trends.

The banking system is increasingly concentrated. This is true in absolute terms and vis à vis the economy as a whole (Demirguc-Kunt and Huizinga 2011). This also means that big banks grow at the expense of other banks (Ötker-Robe et al. 2011). For instance, in 1983, only one US bank had total assets of more than 3\% of GDP: in 2007 there were nine; however the crisis bankrupted some and so there are now fewer and they are bigger (Johnson and Kwak 2010). This is also true globally: "In 1990, assets of the top 25 global banks totaled almost USD 7,000 billion, which accounted for about $30 \%$ of the worldwide GDP. Just before the start of the present financial crisis, their total assets came to almost USD 40,000 billion, 70\% of the worldwide GDP" (Dombret and Lucius 2013). ${ }^{3}$ Among other factors, concentration was facilitated by deregulation and technological advances (Laeven et al. 2014).

\footnotetext{
${ }^{3}$ See also Kaufman (2002), Ötker-Robe et al. (2010), Scherer (2010), Shull (2010), and Haldane (2010).
} 
This tendency also has implications for income distribution, as Minsky (1990) pointed out: "A highly centralized system with a few big banks is not desirable if the aim is to achieve a wide distribution of wealth and a multiplicity of independent economic agents."

General growth and concentration were helped by the friendly stance of banking supervision. Bigger banks were considered to be more stable because they had a more diversified business, better organization, and more diversified risks (Johnson and Kwak 2010), justifying a friendly regulatory approach that meant higher financial leverage (Haldane 2009a) and pushed all the banks in the same direction so that "[i]n essence, the financial network has over time become progressively more complex and less diverse" (Haldane 2009c). In this picture, the originate-to-distribute (OTD) model was considered good, as it pushed risks off the banks' balance sheets (Dombret and Lucius 2013). In general, financial risks were passed from banks to the final consumers and this was considered efficient (IMF 2006). It was not. Of course deregulation was not a "free choice," rather it was forced by the sheer size (and then economic and political weight) of finance. In fact, when policymakers chose stability over innovation, it worked well for the states (Haldane 2010) but not for banking profitability in the long run.

Financialization and globalization yielded unprecedented inequality in income and wealth distribution. The possibility of using the world's population as a single labor market decreased wages and started a downtrend of economic growth (Palley 2007; see also Travaglini 2009; Rajan 2010; and OECD 2014). This has also had negative effects on social mobility (Wilkinson and Pickett 2009; see also Turner 2012; Hein 2013; and Kumhof, Rancière, and Winant 2015). It is now acknowledged that financialization and income distribution are linked.

Industrial and post-industrial economic systems are characterized by two unambiguous phenomena which are at the center of discussions on the current crisis: the increase of the profit share over the past thirty years and the increased degree of financiarisation [sic] of the economic systems. (Bellino 2010) 
The financialization is not understandable in the mainstream theoretical picture (Radde 2012); on the contrary, Minsky pointed out that "[a]1l too often the banking and financial system is an instrument that promotes inequality" (Minsky 1990).

Inequality was compounded by fiscal policies and labor market deregulation (Alvaredo et al. 2013; see also Jaumotte and Osorio Bruiton 2015). Upward redistribution of fiscal policy towards the rich does not mean only a change in the tax rates but also the growth of tax havens, legalizing loopholes, and so on (Strange 1996). Deregulation also had a strong impact on income distribution (Dombret and Lucius 2013; see also Korinek and Kreamer 2014). Added to downtrending wages was a similar trend for public pensions that meant a growing role for private pension schemes. The growth of "institutional investors" played an important role in inflating bubbles while reducing public resources (Toporowski 2000). Lower wages meant a drop in personal saving and a surge in personal debt, two crucial developments that foster financial instability (van Treeck 2013; see also Atkinson and Morelli 2015). Blaming the saving gap on financial illiteracy - as mainstream economics does — cannot help (French et al. 2010). The OTD model also contributed to inequality via financialization and by increasing banks' profits (Lapavitsas 2008).

The situation pushed economists to go back to a Minskyan explanation of the link between inequality and financial stability because "the concomitant rise in inequality and financial fragility may be due to coincidence rather than causality" (van Treeck 2013). In fact, capitalism can survive any inequality as long as the latter does not trigger instability; however, financialization does exactly this (Minsky 1990).

Globalization, concentration, and deregulation brought about a reduction in the diversity of the operators and in the possibility of diversifying risks. It has been noted that "[g]lobalization leads to much closer correlation among markets in different countries and different asset categories" (Pozen 2010). Market co-movements are increasing (BOE 2010; IMF 2011) and there is evidence of a "declining trend in the cross-country dispersion of equity premia worldwide" (Evanoff et al. 2009). This trend is strictly linked 
to the rise of big banks in that the more they diversify, the more similar become:

Banks' balance sheets, like Tolstoy's happy families, grew all alike. So too did their risk management strategies. Financial firms looked alike and responded alike. In short, diversification strategies by individual firms generated a lack of diversity across the system as a whole. $\left(\right.$ Triana 2009) ${ }^{4}$

From an individual firm perspective, these strategies looked sensible, but for the system as a whole they generated greater fragility (Haldane 2009b). More concentration means higher systemic risk (Wagner 2010). So much for the benefits of financial innovation in the diversification of risks, including the OTD model (Evanoff et al. 2009).

Globalization, concentration, and deregulation also mean growing interconnections among banks. The mechanism is the following:

Any asset portfolio is, in essence, a financial network. So the balance sheet of a large financial institution is a network, with nodes defined by the assets and links defined by the correlations among those assets. The financial system is similarly a network, with nodes defined by the financial institutions and links defined by the financial interconnections between these institutions. (Haldane 2009b)

The most dangerous aspect is that the complexity of the networks is such that the true interconnectedness among banks is not visible before a crisis (Kohn 2009), so the system produced banks that "are not only too big to fail but, in having important relationships with a large number of other institutions, are also too interconnected to fail" (BIS 2009). And yet, although a small club, systemically important financial institutions (SIFIs) cannot cooperate to save themselves when things get messy, as the Lehman Brothers fiasco showed conclusively (Sorkin 2009).

The bigger the bank, the bigger its political power. Many commentators underlined that big banks were saved not only for economic reasons. Big banks nowadays are political powerhouses: "The financial services industry is now the most powerful political force in

\footnotetext{
${ }^{4}$ See also the comments in: http://economistsview.typepad.com/economistsview/2013/02/the-case-for-andagainst-too-big-to-fail-banks.html.
} 
Britain and the US" (Kay 2009).

This power is reflected everywhere. Wall Street can use, of course, the sheer power of money (i.e., lobbying), but it can also count on an even more powerful weapon: the cultural hegemony, or the idea that what is good for Wall Street is good for the US (and the world). In a sense, this is even worse than open corruption.

[T] he American financial industry gained political power by amassing a kind of cultural capital - a belief system. Once, perhaps, what was good for General Motors was good for the United States. In the last decade, the attitude took hold in the US that what was good for Big Finance on Wall Street was good for the United States. The banking and securities industry has become one of the top contributors to political campaigns, but at the peak of its influence it did not have to buy favors the way, for example, the tobacco companies or military contractors might have to. Instead, it benefited from the fact that Washington insiders already believed that large financial institutions and free-flowing capital markets were critical to America's position in the world. (Stiglitz et al. 2009)

This is well witnessed in the transformation of parties like the Democrats in the US or the UK's Labour Party in the 1990s. For instance, the Clinton administration was close to Wall Street's weltanschauung (Rubin, Summers) and the few that dared to object (as Reich) were dismissed (Johnson and Kwak 2010). As for Labour in the 1970s: "The left in the British Labour Party was able to secure the passage of a conference resolution to nationalise the big banks and insurance companies in the City of London, albeit with no effect on a Labour government that embraced one of the IMF's first structural adjustment programmes. We are still paying for the defeat of these ideas" (Panitch 2009). The BlairBrown governments were a case study on UK / Wall Street (the City) weight on public policies. This reversed centuries of distrust in the banking system on the part of the government. For instance, the US had a long tradition of famous politicians that were enemies of big banks (Jefferson, Theodore Roosevelt, etc.; see Johnson and Kwak [2010]). Franklin D. Roosevelt succeeded in reducing the power of Wall Street for half a century. Now banks have the upper hand and no politician with a career to defend dares to defy them. 
At the lower level of the administration, the "revolving door" system meant that many important public servants in charge of banking regulation are former Wall Street managers, a situation mocked as "Government Sachs" (Sorkin 2009). ${ }^{5}$ This cultural hegemony has many effects. First of all, the strong competitive advantage of being big means that "empire building" was the name of the game (Moosa 2010). Achieving the status of too big to fail was decisive and the immediate profitability was irrelevant to the merger, as size was a way to acquire power (Berger et al. 1999). Moreover, the bigger the bank became after the merger, the heftier the top managements' bonuses. The culture of big bonuses was so ingrained that it persisted the aftermath of Lehman Brothers. In 2008, Wall Street (saved by public money) paid $\$ 18.4$ billion in bonuses, with six out of nine banks saved by public money paying more bonuses than they made profits in the year (Pozen 2010). How true that, as Hoenig stated: "So long as you have too big to fail, you will have oligarchies" (Stiglitz et al. 2009).

The new state/bank relationship can also be seen in the fate of failed management. After the savings and loan (S\&L) crisis, thousands of managers were jailed; after the collapse of 2008, not a single one was jailed (Wray 2011c) because with the subprime crisis no rules were violated. But this only confirms who inspires the laws nowadays.

Deregulation and public policies in general helped the trend. This was a vicious circle: "The big banks in this country became much more powerful in economic terms and political terms with deregulation in the 1980s, [and with] the arrival of new technologies, particularly derivatives, in the 1990s. And they plowed this political influence back into further deregulation" (Stiglitz et al. 2009). In many ways, deregulation rewarded recklessness (Panico et al. 2012). Paradoxically, the burden of regulation played the same role, because the compliance costs have a big fixed costs component, so the more complex the regulation, the higher the minimum size to compete.

\footnotetext{
${ }^{5}$ For a recent scandal, see: http://www.vox.com/2014/9/26/6849287/federal-reserve-fed-goldman-sachsthis-american-life-carmen-segarra.
} 
All in all, nowadays big banks rule the roost and they do it for their own good. In contrast to traditional economic wisdom, the financial sector cannot be left to the invisible hand because banking is impossible without the state: "The idea that banking systems can exist outside a system of government regulation is simply a Libertarian fairy tale" (Calomiris and Haber 2014). In fact mainstream economics also acknowledged big banks' antisocial behavior: "At the highest level, there is a conflict of interest between society as a whole and the private owners of financial institutions [...] The result is privatized gains and socialized losses" (French et al. [2010: 18]; see also Lastra and Wood [2010]). Therefore, as eliminating the idea of private property altogether seems too extreme, the only solution is to contain the big banks: "the advice from those with experience in severe banking crises would be just as simple: break the oligarchy. In the US, this means breaking up the oversized institutions that have a disproportionate influence on public policy." (Stiglitz et al. 2009).

The basic tenets of mainstream economics did not help. Many hypotheses of the orthodox paradigm were weak and the weakest point was the microfoundation bias: the idea that if something is good for a bank, this automatically yields a better general outcome (Skott 2012). However, the world is not Arrow-Debreu compliant. The confusion between micro and macro arguments is obvious also in the way banks work (Jakab and Kumhof 2015). This also had consequences for the assessment authorities made of them, as Goodhart (2010) pointed out: "The implicit idea was that if you made all banks copy the principles of the best, then the system as a whole would be safe. Hardly anyone critically examined this proposition, and it turned out to be wrong" (Goodhart 2010). Micro-macro transposition also failed because it entails statistical independence: "these models assumed statistical independence. They would not work if everyone used them" (Persaud 2008). This meant that what was considered impossible actually occurred, and the world economy is still paying for these wrong assumptions.

Back in August 2007, the Chief Financial Officer of Goldman Sachs, David Viniar, commented to the Financial Times: "We are seeing things that were 25-standard deviation moves, several days in a row." To provide some context, assuming a normal distribution, a 7.26-sigma daily loss would be expected to occur once every 13.7 billion or so 
years. That is roughly the estimated age of the universe. A 25-sigma event would be expected to occur once every 6x10124 lives of the universe [...] Fortunately, there is a simpler explanation - the model was wrong. (Haldane 2009b)

Technical complexity wrongly induced self-complacency. Banks and credit rating agencies (CRAs) used very complicated mathematical models, but it was nothing similar to science. It was a beauty contest all along. For instance: "triple-A ratings only represented 1 percent of Fitch ratings of corporate finance products in contrast to roughly 60 percent of global structured finance products" (Brancaccio and Fontana 2011). This also explains why the idea that "the markets" know better (than regulators) is simplistic. For instance, Yellen (1996) noted: "As supervisors, not practitioners, we can never hope to be truly on the frontiers of credit risk practice." However, "frontier" is another name for a beauty contest.

The model risk would have been a problem anyway, but concentration and deregulation increased it enormously. The former because it reduced the diversity among risk management styles and models, the latter because it encouraged banks to use risk management to increase profitability. When market standards became regulatory standards, model risk became a lethal danger for banking supervision:

[W]e cannot use risk models that rely on market prices as the instruments of financial regulation. Market prices cannot save us from market failures. Market prices do not predict market crashes; if they did crashes would not occur. (Persaud 2008)

The Basel Committee accepted the internal model because it was more advanced and efficient than the standard regulatory ones. What was not understood beforehand was that micro-efficiency can provoke an increase in overall financial fragility. Systemic risk was not an issue before the crisis. Macroprudential supervision and liquidity risk are barely mentioned before 2008 in international regulation. This had direct and dire consequences for microprudential supervision, too. 
The Financial Services Authority, which was widely regarded as one of the most effective, forward-looking supervisory authorities in the world, provided an especially egregious example with regard to its oversight of Northern Rock. Just weeks before the bank collapsed, supervisors authorized it to adopt the advanced internal measurements approach to risk weighting its mortgages, which reduced its required capital by $30 \%$ and permitted that amount to be paid out to shareholders. (Calomiris and Herring 2013)

When finance becomes "too much" for the economy to handle, microprudential supervision cannot fulfill its duties (Arcand et al. 2012).

Systemic risk is increasing. Increasing banking concentration means a surge in systemic risk. This is a fundamental issue and one that cannot easily fit in mainstream economics, which is micro-based (i.e., it does not find a role for social or systemic concepts). At most, "systemic" could be used to refer to the payment system (Crockett 1997). Indeed the efforts to reduce this source of systemic risk have been strong and rewarding: during the crisis the payment system was never an issue.

After the crisis everything changed and now there is a great effort to understand it. This means the need for data (Cerutti et al. 2012), ideas on how to measure it (Tarashev et al. 2010; Acharya et al. 2010), and connect it to microfoundations (Bijlsma et al. 2010), and so on. Economists are now aware of what seems to be a paradox: the more risks are diversified and the more interconnected the banks are, the higher the systemic risk becomes (Battiston et al. 2012). This is also true for derivatives or the process of securitization, which allows for more efficient risk management while also increasing systemic risk (Evanoff et al. 2009).

In many ways, the momentous return of systemic risk should reduce the importance of microfoundations. As noted in Kambhu, Weidman, and Krishnan (2007): 
A popular fascination of theorists in all disciplines, because of the potential for mechanistic understanding, has been with systems in which the dynamics at one level can be understood as the collective behavior of aggregates of similar units [...]. That is an appealing mechanism, if it was true. But it is not true for the financial system or the economy as a whole. The economy is a network of heterogeneous, not similar, agents.

Stiglitz (2010: 149) raised the same point in practice:

[E]ven if a given bank was managing its own risks well, that doesn't address systemic risk [...]. If all banks use similar models, then a flaw in the model would, for instance, lead all of them to make bad loansand then try to sell those loans at the same time. And that is precisely what happened.

We need different theoretical connections between micro and macro, a "macrofoundation of microeconomics," as Bellofiore and Ferri (2001) observed about Minsky's analysis. ${ }^{6}$

Before the crisis, the links between financial innovation, deregulation, and systemic risk were also neglected (Galati and Moessner [2011]; see also Kling [2009]). The crisis convinced authorities to go full circle from micro to macro (Basel III vs Basel II; see below) and many economists now propose reducing regulation to macroprudential supervision (Brunnermeier et al. 2009).

The role of innovation is to give a boost to profitability, but more profits inevitably mean more risks. Innovation is a way to escape competition, as Adam Smith explained long ago. As the "new" (sector, product, procedure, asset - the "new" for short) is more profitable, competitors start to flock (bandwagoning). The speed of this process depends on regulatory restrictions. Therefore, deregulation helps innovation but also contributes to instability (Loranth and Sciubba 2000; Laeven et al. 2014). This is the paradox of profitability the classical economists had in mind: for the single firm innovation makes perfect sense as it entails higher profits, but when it spreads, the rate of return on the "new" converges to the average rate, forcing further innovation. Innovation is together

\footnotetext{
${ }^{6}$ It is worth noting that there are economists that, while being sympathetic to Minsky's ideas, underline that his financial instability hypothesis is a micro theory that cannot be passed on for a macro analysis (for instance, Passarella [2012]), although others have replied to their critiques (for instance, Caverzasi [2013]).
} 
necessary and self-defeating. Innovation cycles also mean bubbles, as they imply a rapid increase in investment in the "new." Innovation and instability are one and the same thing. As Thakor (2010) put it: "crises can be prevented only if financial innovation is avoided, too."

The link between innovation, competition, and instability is not lost on mainstream finance theory. Although the general message is that innovation is good for overcoming poorly designed regulation (Merton 1995; Tufano 2002; Stiroh and Strahan 2003), many studies underline the danger coming from innovation in terms of instability (Bolt and Tieman 2004; Boyd et al. 2006; Jiménez et al. 2007; Boot and Marinč 2007; Berger et al. 2008). There are many trade-offs, as Allen and Gale (2004) put it:

\footnotetext{
Competition policy in the banking sector is complicated by the necessity of maintaining financial stability. Greater competition may be good for (static) efficiency, but bad for financial stability. From the point of view of welfare economics, the relevant question is: what are the efficient levels of competition and financial stability?
}

The most important message here is that the stance of regulation cannot be taken as exogenous. It is connected to profitability: banks needs to overcome a slowdown in profitability, so they turn to innovation (Kregel 2012). Regulatory innovation is part of the process (Boz and Mendoza 2010). Innovation boosts profitability, thus sparking bubbles. Banking regulation, like every part of the financial system, is procyclical. Many commentators observed it before the crisis, but only in specific contexts (the loan-tovalue ratio is procyclical, credit rating standards are procyclical, and so on; see, for instance D'Amato and Furfine [2004]; Kashyap and Stein [2004]; Fostel and Geanakoplos [2008]; Van Roy [2008]). That regulation can increase the procyclicality of the system was also common knowledge (Taylor and Goodhart 2004; Gordy and Howells 2006; Repullo and Suarez 2008; Drehmann et al. 2010; Miao and Wang 2014). Moreover, it was also acknowledged that regulation is biased in favor of big players (Strange 1996), even if, paradoxically, these firms are the smartest in regulatory avoidance (Kane 1981). As profitability is attacked by competition, and innovation and deregulation are the inevitable consequences, the only assured thing about financial 
regulation is that it will be overwhelmed (French et al. 2010), as Minsky also observed. We will come back to this important issue.

Innovation yields commoditization and vice versa. The cycle cited above (downward pressure on profits leads to innovation and then to a bubble, which ends in a crisis) is also connected to a commoditization trend. When the new is no longer new because innovation has been generalized, it becomes a commodity driving down profits (Merton 1995). An example:

\begin{abstract}
Ken Moelis, a veteran banker who now runs his own firm, recalls that when he started in the industry in 1981 at Drexel Burnham Lambert, a firm that pioneered the high-yield bond market, "there wasn't another firm in the world that knew how to price a junk bond," so issuing and trading them was enormously profitable. These days, he says, they can be traded and their prices discovered electronically down to three decimal places. (The Economist 2013)
\end{abstract}

If we start from the assumption that risks (and even more uncertainty) are needed to bring profits, it becomes obvious that finance needs risks (among many, including Lapavitsas [2008]; Rajan [2010]; Acharya et al. [2010]). As Haldane (2010) explained: "Finance theory tells us that risk brings return. So there are natural incentives within the financial system to generate tail risk and to avoid regulatory control."

In the final stage of the cycle, when the formerly new activity is completely standardized and the return it yields is low, competition induces reckless behaviors. For instance, just before the crisis, debt issuers shopped for a better rating among CRAs (Pozen 2010) and financial advisors used sex to sell subprime mortgages. ${ }^{7}$ The fiercest and ruthless competition was a warning that the bubble was coming to an end:

Nothing is more dangerous than a good idea. That ominous generalization seems inescapable given the development of finance over the past 40 years. Time and again, business has seized upon a new idea - junk bonds, LBOs, derivatives - only to push it far past its sensible application to a seemingly inevitable disaster. (Pare 1995: 197)

\footnotetext{
${ }^{7}$ http://www.bloomberg.com/bw/stories/2008-11-12/sex-lies-and-subprime-mortgages.
} 
Moderation is definitely not the name of the game. Banking supervision should reflect this basic aspect.

Profitability is the North Star of the system. Every trend we have commented on so far (concentration, innovation, deregulation cycles, and so on) can be brought back to profitability.

In particular, the cycles lowering of profits/deregulation yielding innovation/bubble/commodification and then crisis/reregulation explains the finance system of at least the last three centuries. When profits are good, there is no need for innovation and deregulation (Johnson and Kwak 2010), but when returns are falling, anything is attempted. For instance, reregulation after a crisis can hamper profitability for a while. It is true that when this happens for every bank, they all suffer a reduction in profitability and competition is not modified, but the change in profit rates will produce nervousness in the top management (BIS 2011). One can argue that the lowering of interest rates and other public policies are easily explained in terms of profitability: "The gains risk being privatized and the losses socialized. Evidence suggests this is a repeated historical pattern" (Haldane 2009a). Another example is the composition of banks' liabilities. In the 1970 s, it was fairly normal for a big bank to have $20 \%$ of its balance in very liquid assets, and the decline in the liquid part of liabilities was very strong until the crisis (BOE 2010: 34); this was allowed by weaker banking regulation. More generally, economic policies cannot be understood without considering the profitability trends. This is true for fiscal and monetary policy as well as for market regulation. In discussing how to better regulate the banks, this issue cannot be overlooked.

We should also recall that the relative power of the different sectors of the economy is basically measured from their size in terms of profits. It is not by chance that there is a historical trend toward an increase in financial profits as a share of total profits (Guttmann and Plihon 2010) that is difficult to link to the "superior" efficiency of big banks. A higher return on equity (ROE) was linked to higher leverage instead as big banks accrued more losses than other, smaller banks (Goldstein and Veron 2010). 
Who pays for the crisis? Financialization rewarded unfairness. It is difficult to assess precisely the economic impact of the crisis (although many have tried, as we will see). For sure, the scale of intervention is without historical precedent. In the 1980s, the US Government Accountability Office (GAO) estimated the cost of S\&L crisis at $\$ 150$ billion, a figure that was considered outrageous (Hetzel 1991). After 2008, this figure seems argent de poche. Although it is difficult to put together different policy expenses (for instance, direct recapitalization, lending of last resort, implicit guarantees, and so on), the numbers are astounding. Below we give some examples.

From 2008 to 2011, banks in the US and EU were forced to raise \$1.4 trillion in new capital (Brei et al. 2011), an amount that is nearly equal to the GDP of Spain. Haldane (2009a) estimates the cost to save these same banks at $\$ 14$ trillion, "or almost a quarter of global GDP." Estimates for mending the crisis as a whole are even higher: \$24 trillion for the US government (Johnson and Kwak 2010) and \$19 trillion for US households, or "almost two decades of accumulated prosperity" (Better Markets 2012: 33). For the whole world the figure is $\$ 60-200$ trillion (Dombret 2013).

Comparing the total costs of the crisis and the costs of recapitalizing the banks, it is obvious that if big banks had been called to shoulder the real costs of their actions they would be bankrupt, even if the costs had been distributed among the profits over the course of their entire lifespan and even without considering the implicit subsidies like deposit insurance and the possibility of tapping central bank money. Using the real costs of banking, it is not profitable as it seems. Probably it is not profitable at all.

\section{BUBBLING BANKS}

Mainstream economics has always denied, in its core intuitions, the special nature of banks (for instance, Freixas and Rochet [2008]). This is also because of disintermediation, a tendency assigned to different sources over time but all converging to the outcome of a diminishing importance of the banking industry (Marotta and 
Pittaluga 1993). Banks, for their part, did not seem impressed by this memento mori, and insisted on growing in size and power. We will analyze here the cultural environment that contributed to the crisis, especially for its consequences on banking regulation.

\subsection{The Cultural Side of the Bubbles}

And we will never return to the old boom and bust. — Gordon Brown (in Summers 2008)

The flourishing of bubbles always came with a cultural and academic optimism bordering on mindless drunkenness. The process of financialization produced bigger and bigger bubbles and hence wilder cultural and academic euphoria. It should be acknowledged when proposing a new regulatory framework that a bubble is connected to the aforementioned cycle related to the creation of something "new." Galbraith (2001: 250) explains:

\footnotetext{
The more obvious features of the speculative episode are manifestly clear to anyone open to understanding. Some artifact or some development, seemingly new and desirable [...] captures the financial mind [...]. The price of the object of speculation goes up [...] This increase and the prospect attracts new buyers; the new buyers assure a further increase. Yet more are attracted; yet more buy; the increase continues. The speculation building on itself provides its own momentum.
}

To escape the downward trend of the established sectors, something "new" is introduced. Business cycles are investment cycles and investment cycles are connected to bubbles (Shiller 2009). As we saw, the bubble starts because the "new" yields a higher riskweighted profit rate. Like the beginning, the end of the bubbles is also always the same:

For built into this situation is the eventual and inevitable fall. Built in also is the circumstance that it cannot come gently or gradually. When it comes, it bears the grim face of disaster. That is because both of the groups of participants in the speculative situation are programmed for sudden efforts at escape. (Galbraith 2001: 250-51)

Even though the birth and death of bubbles is unmistakably similar, their lifespan is unpredictable. Nobody knows how long a bubble will run because it depends on how many investors keep coming in. This means that the only mechanism for explaining the 
bubbles is the beauty contest. This was understood well before Keynes. ${ }^{8}$ Since at least the tulip mania, these phenomena are not only similar in their economic mechanisms but also in other aspects that connote the bubble (such as wild optimism and subsequent panic) and can be called the "this time is different" syndrome. As the timespan of a bubble depends crucially on the beauty contest, this behavior is completely rational. To be manic is rational provided that many others keep the mania going.

The mania affects everything: universities, authorities, media (Toporowski 2010). Even in popular media, like movies and TV series, there is a growing role for the romantic depiction of swindlers, thieves, and so on. This cultural domination is more pervasive than direct (legal and less legal) access to governments and media, although, needless to say, it helps having friends in the government and this is assured by the revolving door that implies that the intellectual outlook of important people is aligned to Wall Street's. The main component of this outlook, and the basic idea behind monetarism and globalization, is the idea that the state and whatever is public is not relevant or useful and finance should be left alone to lead the planet (Strange 1996).

The bubble atmosphere includes the idea that there is something completely new and different from the past and those who don't understand it must be silenced or marginalized. We can call this "survival of the blindest" - whoever is not ready to cheer should be ready to leave or at least to be quiet. During the bubble everyone that opposes the mania is criticized, regardless of their importance. It happened to a famous banker, Paul Warburg, before the crash of 1929. It happened to many others more recently. This is particularly worrisome, because anyone who tries to alert the world to the bubble is most irrelevant just when the bubble is poised to produce the most damages.

In those periods, inside the banks the tug of war between the profit side (traders, bankers, etc.) and the cost side (risk managers and the like) is particularly unfavorable to the latter and the strength of a bubble can be measured from how irrelevant they are. When, just

\footnotetext{
${ }^{8}$ See, for instance, the famous pamphlet, Confusion de Confusiones, published in 1688 by the Jewish merchant De la Vega that proposed the very same idea.
} 
before the collapse, Raghuram Rajan (2010) asked too many risk managers why they were acquiescent to strategies they deemed irresponsible, they replied: "you must understand, anyone who was worried was fired long ago and is not in this room." For the banks it was only natural to select managers who were gung-ho for the bubble. This is also clear from this one-sided official statement from James Chessen, chief economist of the American Bankers Association, a few months before the crisis: "The banking industry is in exceptional health" (Bair 2012: 24).

Interestingly, many top managers were conscious that a dangerous mania was going on but they had no alternative. As the former CEO of Citigroup, Chuck Prince, very aptly said:

[W]hen the music stops, in terms of liquidity, things will be complicated. But as long as the music is playing, you've got to get up and dance. We're still dancing. (Nacamoto and Wighton 2007)

Then all of the sudden the music stopped.

Scientifically speaking, the situation was similar. First of all, in the Arrow-Debreu world, banking, finance, and even money do not have a true space because "[i]f markets were complete, financing and insuring would be trivial" (Philippon [2008]; see also Panico et al. [2012]; Dombret and Lucius [2013]; Kregel and Tonveronachi [2013]). Although banks and finance cannot fit into the orthodox theoretical framework, mainstream economists draw practical conclusions as though they could. This means that they misled authorities before and during the crisis. In fact, they denied the very possibility of a crisis to begin with. A typical example of this is a book like The Economics of the Great Depression (Parker 2007), where a rerun of 1929 is ruled out and Minsky is not even mentioned. In his contribution, Cecchetti (2007) notes the capital ratios of the banks were a lot lower than in ' 29 but everything was fine nonetheless. He stated: "Today we let banks fail but we do it in a way that is designed not to create panic. A bank failure today will almost be invisible to its customers because it will be done over a weekend." Not quite the case, as with Lehman Brothers. 
Secondly, even if a crisis materialized for whatever unlikely reason, it would be over more quickly (Greenspan [2007], among many). In the meantime, just leave the banks alone and everything will be fine. This was the distilled wisdom of orthodoxy. We give only a couple of citations: "[the] private sector has much better incentive to create financial institutions that will make the financial system operate efficiently" (Mishkin 2002); and "[m]arket discipline should reduce the bank manager moral hazard problem of excessive risk taking by making the bank pay the actual cost of its risk taking" (Freixas and Rochet 2008). Many supported the reliance on market discipline, but the results have been far from positive (Masciandaro et al. 2013). Economists were proudly united behind the "new consensus." It has been noted that until August 2008, the then chief economist of the IMF, Olivier Blanchard, could state how useful mainstream economics was by saying:

\begin{abstract}
Macroeconomics is going through a period of great progress and excitement, and that there has been, over the past two decades, convergence in both vision and methodology [...]. This was a view shared by many academics and practitioners: the degree of consensus achieved in macroeconomics has been unprecedented since the "Golden Age" of the 1950s and 1960s. It is not a case that this view was labelled the New "Consensus" Macroeconomics. (quoted in Brancaccio and Fontana [2011])
\end{abstract}

The most "Keynesian" part of the orthodoxy could accept some short-term rigidity as a tool to reconcile reality with the paradigm, as in the dynamic stochastic general equilibrium (DSGE) models. In the long run all rigidities were dead and the world returned to being perfectly neoclassical. Anyway this strand of Keynesianism had no use in finance, as Mervyn King, former Governor of the Bank of England, pointed out (Turner 2015).

As part of the ruling cultural environment, conclusions stemming from mainstream economics could not be defied, only deified. For instance, in 2005, Rajan was lambasted for having timidly exposed some drawbacks of financial globalization. ${ }^{9}$ Regulators like

\footnotetext{
${ }^{9}$ As anyone can read in the now-famous paper, Rajan (2005) is extremely cautious and always couples critiques with praises. For instance: "The broad participation has allowed risks to be more widely spread throughout the economy"; on securitization: "pooling reduces adverse selection"; on interconnectedness: "advantages of interlinked markets are many"; and at the end "I believe the changes have, in general,
} 
the former chief of the Commodity Futures Trading Commission, Brooksley E. Born, or Shelia Bair (then President of the FDIC), were attacked during public conferences because they dared to put some doubts on market friendly regulation. For the operators the good side of the mainstream theories was that theories like the efficient markets hypothesis (EMH) allowed, via Black-Scholes-Merton model and the like, for the creation of new markets, thus expanding the bubble (Johnson and Kwak 2010). This was not secondary in the process of economic trivialization. As Johnson put it:

\begin{abstract}
The seduction extended even (or especially) to finance and economics professors, historically confined to the cramped hallways of universities and the pursuit of Nobel Prizes. As mathematical finance became more and more critical to practical finance, professors increasingly took positions as consultants or partners at financial institutions[...] One effect of this migration was to lend the stamp of academic legitimacy (and intellectual intimidation) to the burgeoning world of high finance. (Stiglitz et al. 2009)
\end{abstract}

Thus, theoretical and practical euphoria merged to fuel the bubble. The early warning, in the form of the Long-Term Capital Management (LTCM) demise, fell on deaf ears. The fact that Nobel Prize winners did not grasp the core essence of financial markets was not considered of any importance.

\title{
3.2 Bubbling Banking Regulation
}

Profound effects of this cultural and scientific environment were experienced by banking regulation. Even central bankers were captured by the bubble and proposed ideas such as those proposed by Donald Kohn in 2007: "we need to have faith in the invisible hand" (Dombret and Lucius [2013]; see also Carré and Gauvin [2015]). This faith meant deregulation. As Scott G. Alvarez, General Counsel of the Fed, put it: "the mind-set was that there should be no regulation" (Bair 2012). Markets are efficient, banks are efficient. Everything seemed to go in the direction of a safer environment. This was true for derivatives (enthusiastically praised in the IMF's Global Financial Stability Report of April 2006) or securitization. Banks were smarter than ever in managing risk: "More precision in estimating risk is tantamount to a reduction in risk [...]. Larger, more

expanded opportunities significantly and have, even on net, made the world tremendously better off." This prudence was to no avail. 
diversified loan pools may result in overall risk reduction" (Yellen 1996). Therefore, even prudential regulation was useless. Why use ratios and other prudential regulation tools when the market will monitor the banks (Holmstrom and Tirole 1997)? Even experts on the 1929 Depression, like Ben Bernanke, who denied any risk of a housing price bubble, were dragged by the tide (Bellamy, Foster, and Magdoff 2008).

Since the start of the Basel Committee, any significant changes in banking regulation have come as a consequence of a banking crisis and when that crisis ended, attacks on the new regulation started to arise. In the case of the framework of Basel I, the main accusation was that it was too simplistic and prone to arbitrage. Instead of preventing arbitrage, the idea was to make it legal. In 1995-96, the Basel Committee proposed amending the agreement by adding requirements for market risks. The goal was to improve the link between capital and the risks assumed by banks (BCBS 1996). The main feature of the amendment was that it took into account the request of the banks to adopt their own internal models to measure exposure to market risks as an alternative to standard regulatory measures. The idea seemed obvious: given that banks' models were more advanced than regulation, why not use them for supervisory purposes? This philosophy was extended to all types of risk with Basel II. The effects are now clear. Every bank developed an internal model to reduce its capital requirements, showing the market and the regulators that the opposite was occurring. The micro-efficiency detonated the macro-bubble.

When someone proposed putting a backstop on these models, for instance with a leverage ratio, they were considered Stone Age shamans (Bair 2012). Empirical analyses seemed to favor this trend (for instance: "the probabilities of bank failure are lower under Basel II than under Basel I" [Repullo and Suarez 2008]). The very idea of stopping a bubble was considered irresponsible. Inflation targeting was good, asset targeting was not. The continuous growth of the financial sector in the world economy was good, too: "Thanks to advances in communications, computing, and financial know-how, the financial sector's size and share in value added have increased over time" (BIS 2010: 75). Why the same advances were not helping other sectors was not explained. On the same token, the 
banking systems experiencing growth were the best. The IMF gave a very positive review to Ireland in 2006 with its Financial Sector Assessment Program Update, although Allied Irish Bank (AIB), one of the "big four" banks of the country, was growing its assets at $40 \%$ a year (Caprio 2013).

Before 2008, the crises seemed confined to single sectors or distant countries, and was attributed to specific problems (the IT bubble, Enron, crony Asian capitalism, and so on). The solution was more deregulation and privatization. The case of LTCM, which we already mentioned, did not help, as the crisis was stopped by the heavy pressure of the NY Fed on big banks to bail it out. From then on, crises after crises ensued, until the "big one" shocked the world economy. As an apt epitaph to that world we can quote Greenspan: "I was wrong" (Caprio 2013).

The most important and worrisome lesson we can draw from this episode is that the "this time is different" syndrome and bubbles cannot be eradicated from the system, as they are tantamount to profit maximization. After a crisis, everybody will say "this time we got the lesson," just like a drunk announces he will never drink again. This is cheap talk. The economy has its iron logic; economics can only follow.

\subsection{The Rebirth of Common Sense}

Common sense is not so common. - Voltaire (1817)

After such a failure on the theoretical and regulatory front, theory and practice suffered a strong decoupling. Central banks and governments could not afford to wait for economists to mend their models. As Arnold et al. (2012) pointed out: "[N]ot uncharacteristically, policies have moved ahead of academic research: waiting was not an option."

So the idea was, while you guys in the universities think about how to put the world back into your theories, we will try to save the world as we can. This primum vivere sort of practical theory was even theorized, as in Ciocca (2014). For instance, Goodhart (Turner et al. 2010) observed with a bit of an exaggeration: "Financial regulation has always been 
atheoretical, a pragmatic response by practical officials, and concerned politicians, to immediate problems, following the dictum that-We must not let that happen again."

In this context, we will underline some points that we consider the most important flaws of the present paradigm and that, as we will see, are escapable with the Minskyan alternative.

The first point is the quest for microfoundations. When the crisis struck, long-forgotten ideas like systemic risk and macroprudential supervision were frantically brought back from the cellar. Obviously, we rediscovered that "financial stability encompasses more than the sum of individual risks that exist in a financial system" (Dombret and Lucius 2013: XVIII). Micro-based banking supervision is at least incomplete:

The current approach to systemic regulation implicitly assumes that we can make the system as a whole safe by simply trying to make sure that individual banks are safe. This sounds like a truism, but in practice it represents a fallacy of composition. In trying to make themselves safer, banks, and other highly leveraged financial intermediaries, can behave in a way that collectively undermines the system. (Brunnermeier et al. 2009: VII)

Martin Wolfe (2009) made the same point: "individual rationality does not ensure collective rationality." This is nothing new. Kindleberger and Aliber (2005: 47) wrote:

Yet euphoric speculation with insiders and outsiders may also lead to manias and panics when the behavior of every participant seems rational in itself. Consider the fallacy of composition when the whole differs from the sum of its parts. The action of each individual is rational — or would be if many other individuals did not behave in the same way.

Banking regulation, too, was forced to overcome the micro-approach:

The main policy paradigm shift has been the strengthening of the macroprudential, or systemic, orientation of regulatory and supervisory frameworks; that is, the recognition that frameworks focused on seeking to ensure that individual institutions are sound on a stand-alone basis, as prevailed in many jurisdictions, were flawed. It could miss the wood for the trees. (Arnold et al. 2012) 
However, renouncing microfoundations is easier said than done. It is tantamount to renouncing everything connected to market efficiency, from the EMH to the quantity theory of money. When Admati and Hellwig (2013), criticizing the idea that raising capital for banks is socially expensive, wrote that "what is expensive for the banks, need not be expensive for the economy," they denounce (maybe not on purpose) the invisible hand metaphor, the core of mainstream economic thinking for the last 250 years.

The second point is uncertainty. Economists again became aware of the fact that markets are based on genuine uncertainty, à la Keynes (Haldane 2009a; Turner 2012) and risks involved in banking and financing are not objectively measurable. Therefore, riskmanagement procedures are part of the beauty contest (Turner 2015). This is also true for the banking sector. For instance, a credit crunch is due to the fact that "nobody is willing to bear the risk of expanding their balance sheet unless everybody else is expected to do the same" (Alessandri and Panetta [2015], emphasis in the original).

A third point is that ideas are procyclical, just like the markets, and it is useless to think that economists will quit being optimistic, ever after a debacle. As Borio (2012) said:

\footnotetext{
So-called "lessons" are learnt, forgotten, re-learnt, and forgotten again. Concepts rise to prominence and fall into oblivion before possibly resurrecting. They do so because the economic environment changes, sometimes slowly but profoundly, at other times suddenly and violently. But they do so also because the discipline is not immune to fashions and fads.
}

A fourth point is linked to monetary policy. Before the crisis, fiscal policy was considered an unimportant relic and the only public action needed was monetary policy via inflation targeting (Blanchard et al. 2010). This has changed. Now the most important public target is financial stability, and monetary policy faces significant limitations as a tool for promoting financial stability.

The final point is that it is now obvious that financial fragility is endemic and it will get worse (paradoxically) after a long period of stability, as Minsky proposed many decades ago. For instance: "The context is what might be called the "paradox of financial 
instability': the system looks strongest precisely when it is most fragile" (Arnold et al. 2012).

The problem is that for all these observations, the crisis has not yet prompted many changes (Turner 2012). This is true for academia, where Minsky is still heterodoxy, as well as banking regulation, where the regulatory crackdown is constantly watered down and risks becoming ineffective in changing ingrained habits.

Although we know that there are strong reasons why wild optimism is the natural ruling paradigm in economics, we use the disorientation of mainstream theories caused by the crisis to try to expose our alternative.

\section{INVESTMENT, PRICES, AND PROFIT}

In this section we will try to outline an investment theory able to explain how markets and banks really behave.

Classical economists and Marx took for granted that with the development of capital accumulation also came a tendency of the general profit rate to decrease. As for the sectoral rates, competition will induce their convergence towards the average rate. We have thus two converging dynamics: with the maturing of the industry, the profit rates of new sectors tend to shrink and the general rate of profit tends to decrease as capitalism matures. Adam Smith (1776 [2007]: 75) points out this mechanism as follows:

The establishment of any new manufacture, of any new branch of commerce, or of any new practice in agriculture, is always a speculation from which the projector promises himself extraordinary profits. These profits sometimes are very great, and sometimes, more frequently, perhaps, they are quite otherwise; but, in general, they bear no regular proportion to those of other old trades in the neighborhood. If the project succeeds, they are commonly at first very high. When the trade or practice becomes thoroughly established and well known, the competition reduces them to the level of other trades. 
In this context, therefore, it is rational for an investor to buy the new asset, as it yields a higher return. This means bubbles. When a sectoral bubble lasts long enough, it is transmitted to adjacent sectors and then to the economy as a whole. The financial leverage of investors grows with the bubble as the credit flows to finance it. At a certain point, the bubble collapses because it incorporates an assumption that goes against the gravity law of capitalism: the idea that an asset can forever yield a higher-than-average rate of profit, which would mean that profit maximization does not work anymore. Ebbs and flows of profits and of the profit rate explain the trends and cycles of a capitalist economy, including the prevailing economic policies and regulations.

To exist, new sectors must be financed and therefore can be represented as financial assets. This means that investment is tantamount to finance. Therefore, everything in the economy is linked to the financial structures of economic operators and in particular to how investment is funded. This is the source of the business cycle. In this context, investment means uncertainty because of how (in terms of time span and convulsiveness) the new asset's profit rate will tend toward the average is not predictable. The new asset has a higher-than-average yield and attracts investors that fight to finance/buy it, starting a bubble.

Many economists (among them, Kindleberger and Galbraith) have explained and described how a bubble is born, lives, and dies. For our purposes the most important aspect is that, due to uncertainty, there is no way to reach a measurable consensus on future profits of a given asset; therefore the investment cycle is linked to the beauty contest. Fluctuations in investment determine fluctuations in profits, but the former derive from uncertainty about future profits. So the cycle of profits-investment-profits is basically another name for uncertainty and animal spirits. It is even trivial to point out that in good times risks are underestimated and financial leverage goes up, thus transforming respectable bankers into Ponzi fraudsters, mainly malgré eux. We also recall here that this madness is completely rational because if they try to not follow along with the bubble, they are not guaranteed higher returns. 
In this context, money and investment are strictly connected because money is basically (private) credit. Contrary to the old Monetarist idea that central banks are the all-powerful creators of money, money supply tends to escape their control, especially during bubbles (i.e., periods of strong financial innovation). As Merton and many others observed, financial innovation is basically a way to bypass central banking and banking regulation (Corbisiero and Musella 1997). Innovation means higher profits in terms of rate and volume. In fact, financial innovation is linked to the growth of both. Therefore, the loanable funds theory cannot explain how banks behave (McLeay et al. 2014; Jakab and Kumhof 2015).

\subsection{Methodological Consequences of the Beauty Contest}

Before we proceed in explaining the Minskyan perspectives on investment and finance, it is important to explain the consequences of living in a beauty contest / Ponzi world. After the crisis, there was an explosion of debates about so-called "model risk," that is the risk coming from an oversimplified model of how the economy works. Indeed the dominant model was not only simplified, it was wrong. But here we deal with this issue from a more radical perspective: the issue is not that a specific model was wrong, it is that there is no way to formalize the functioning of the beauty contest in any meaningful way. This was absolutely clear to Keynes and Minsky, who were both well-acquainted with mathematics and statistics, but also aware of their limits (Foley 2010). This impossibility goes beyond the Knight-Mises position that markets can solve the problem of uncertainty with their spontaneous functioning thanks to the information gathering of each agent, while economic planning (in whatever form, from Keynes to Gosplan) cannot. This seemingly abstract issue of economic methodology has direct applications in banking supervision, namely that there is no way to anticipate the crisis with a model (with stress tests or early warning indicators). In a sense this is similar to the Lucas critique: if such an indicator exists, "this would result either in an immediate crisis or no crisis at all" (Drehmann et al. 2010). As we can recall, with a necessary lapalissade, "[m]ost flight to quality episodes are triggered by unanticipated or unexpected events" (Caballero and Krishnamurthy 2007). What is the point then in creating a model that only includes anticipated (deterministically or stochastically) events? Although capitalist instability is 
endogenous, it cannot be endogenously formalized.

\title{
4.2 The Role of Innovation
}

Among others, Minsky (1982a) emphasized the dialectical nature of competition, innovations, and banks, showing that ultimately profits and investment are connected through innovation:

\begin{abstract}
A financial innovation which increases the funds available to finance asset holdings and current activity will have two effects that tend to increase investment. The first is that the market price of existing assets will rise. This raises the demand price for outputs that serve as assets (investment). The second is that by lowering the cost of financing for production, financial innovations lower the supply price of investment output.
\end{abstract}

More innovation and more investment yield more profits but also more instability because the longer the bubble is allowed to grow, the higher financial leverage becomes. This mechanism is important in understanding how financial markets work. First of all, the probability distribution of risks of an asset does not exist due to uncertainty and market participants are not interested in probability but in what competitors are doing. Hence the beauty contest is the name of the game, not inference statistics. Secondly, without innovation and uncertainty, profits are doomed to go down. Therefore risks (or better "real" risks that come from investing in new assets) are exactly what market participants look for-what in mainstream economics is called "tail risk" (Acharya et al. 2010). Innovation, investment, uncertainty, and financial bubbles are one and the same thing. This also explains why the epoch of low competition and low innovation entails financial stability.

Innovation also yields a growth in financial turnovers, first in the directly affected segment, then in the financial sector as a whole. This has been rediscovered with the OTD model, but long ago Minsky (1975) noted: “[e]ach new instrument and expanded use of old instruments increases the amount of financing that is available and which can be used for both investment and the taking of positions in inherited capital-assets." 
A second aspect of innovation is that it increases interconnectedness via complexity and others means. All in all, innovation produces more micro-efficiency and more macrofragility. This explains why the longer the cycle is (high profits, high growth), the more fragile the situation becomes. This is the most profound and counterintuitive idea of Minsky (and Keynes). Prosperity is destabilizing because it is built on financial leverage. Practically: i) there is a sharp rise in the price of capital goods (and financial assets); ii) profits on these assets are good so that, apparently, the financial position of operators is not deteriorating but in reality everyone is becoming a Ponzi speculator.

In a system dominated by hedge finance, the pattern of interest rates [...] are such that profits can be made by intruding speculative arrangements. The intrusion of speculative relations into a system of mainly hedge financing of positions increases the demand for assets and therefore raises asset values - that is, it leads to capital gains. A regime in which capital gains are being earned and are expected is a favorable environment for engaging in speculative and Ponzi finance. Profit opportunities within a robust financial structure make the shift from robustness to fragility an endogenous phenomenon. (Minsky 1986b: 210)

At a certain point the bubble explodes. The contingent reasons can be different and are not very important. The core aspect is that, as we have seen, there are strong forces that push for a re-equilibrium of asset yields. Innovation spreads through the market so that profit margins go down and prices with them. Banks realize at their expense how fragile the collateral of the innovators was and hence how Ponzified their balance sheet had become. This trajectory is a confirmation of the fact that uncertainty is the very fabric of the system:

If rational agents doubt the validity of the model that currently guides their actions, then, they stand ready to abandon that model as the behavior of the economy produces data that falsify the model. Whenever a model with a weak degree of belief guides the actions of an agent then, as evidence accrues, initial models are likely to be abandoned and a new set of models be substituted. When this happens, sharp changes in the behavior of agents and of the economy are likely to occur. (Minsky 1996) 
As Keynes insisted many times, uncertainty is linked above all to liquidity because liquidity is what makes the situation of a single agent not relevant as an indicator of the overall stability:

Of the maxims of orthodox finance none, surely, is more anti-social than the fetish of liquidity, the doctrine that it is a positive virtue on the part of investment institutions to concentrate their resources upon the holding of "liquid" securities. It forgets that there is no such thing as liquidity of investment for the community as a whole. (Keynes 1936)

This is the point. Liquidity risk can be managed at a micro level, but for the banking system as a whole this is not possible. The liquidity issue is the direct reason why markets are based on a beauty contest and everything is a convention. It is interesting that Keynes, just before introducing the metaphor of the beauty contest, proposes another metaphor: "it is, so to speak, a game of [...] Musical Chairs - a pastime in which he is victor $[\ldots]$ who secures a chair for himself when the music stops. These games can be played with zest and enjoyment, though all the players know that [...] when the music stops some of the players will find themselves unseated" (Keynes 1936: ivi).

This is very similar to the observation made by Chuck Prince (Nacamoto and Wighton 2007). ${ }^{10}$ Everybody knows perfectly well they are playing a game where someone - and sometimes everyone-will be crushed at the end. These are the rational expectations of this world.

\subsection{Profits Are the Key to Assessing Economic Policies}

Firms react to uncertainty by growing in size and thus increasing overall instability. The role of public authorities is therefore to reduce uncertainty by reducing profit volatility; this is the sense of fiscal and monetary policy, as Minsky put it: "to keep business cycles within bound." Then, the public sector size is linked to the leverage of the economy: the higher the leverage, the stronger the need to stabilize the situation through public policies, because "[b]ig government prevents the collapse of profits which is a necessary condition for a deep and long depression" (Minsky 1982a).

\footnotetext{
${ }^{10}$ The same observation has been made by Amato and Fantacci (2012).
} 
The task of saving profits is necessary to save banks from themselves, but it is also selfdefeating because the very end of the bubble (that also induces the equalization of the rate of return on new and old assets) increases the search for new, high-margins assets ("search for yield") (i.e., for a new bubble, creating what Kalecki called the "increasing risk principle"), a trend that is so entrenched in the profitability needs of the system that authorities are forced to accommodate their policy to it.

\section{THE AFTERMATH OF THE CRISIS AND BANKING SUPERVISION}

In the Formula 1 races, when there is an immediate and significant danger, a safety car enters the circuit until the danger is over, then leaves the drivers alone again. This is basically the role assigned to banking reregulation after the crises. In a nutshell, the reforms go in the direction of deleveraging via risk reduction and capital increase (BIS 2010). In other words, reforms reduce the profitability of the banks for a while to restore financial stability. This is done in many ways besides deleveraging, for example, an increase in compliance costs and reporting duties, (see, for instance [BIS 2011]), a reduction of the interest margin due to loose monetary policy, and so on. The more effective the crackdown, the louder the protests by the banks. After a while, financial innovation and lobbying will succeed in calling back the safety car. The length of the safety car's presence is a precise indication of the relative strength of financial capital vis à vis the state. Franklin Roosevelt succeeded in leaving the safety car on the circuit for decades. After 2008, it was recalled after a couple of laps.

In appendix 1 we will briefly analyze the main reforms linked to banking supervision that were undertaken after the crisis. Here we only observe that many scholars acknowledge the importance of an integrated approach that uses capital measures, liquidity measures, regulations for the internal control systems and other organizational aspects of the banks, and so on in a combined fashion (Blinder 2010). For instance, for big banks the Financial Stability Board (FSB) (2013) is ready to "consider domestic structural measures that are complementary to an effective SIFI framework." However a combined approach has 
many limitations, above all because prudential and structural supervision have different and (in many ways) opposite backgrounds. Proposing their integration is a way to admit that we are in a period of transition, where the prominence of prudential (hence international) regulation is precarious but structural (basically national) supervision is not able to undermine it. The ups and downs of the financial system will decide what kind of supervision will prevail in the future. For now we can only observe that prudential supervision tools are of no utility during a systemic crisis and ordinary structural supervision tools cannot avoid the collapse of diversity in the banks' business model. Together with compliance supervision tools, these tools in their practical implementation strengthen the grip of big banks on the market.

\section{HOW TO REBUILD BANKING REGULATION FOLLOWING MINSKY}

So far we have discussed the main trends of the international financial system, their consequences for financial regulation before and after the crisis, and the ideas of Minsky on investment, financial stability, and banking. We are now ready to put all together. We will start studying what is lacking in the new framework of banking supervision and how to remedy the omissions. This is particularly important because in the field of economic theory we are in a transition period, just like in the 1930s, where reforms were worked out in a period of theoretical transition. So the discussion about banking supervision practice has much to say to theory nowadays.

\subsection{Minsky and Banking Supervision}

The starting point is the link between finance and the real economy in many dimensions, including: growth, income and wealth distribution, unemployment, and profitability (Wray 2011b). As Minsky (1986b) put it: "financial reform can be effective only as a part of a general system of reform." For instance, the concentration of income is linked to the surge of finance, as Panico et al. (2012) observe: "Since the expansion of financial lending can influence the income shares, a society that is committed to the stability of the 
distributive shares should be interested in the introduction of forms of regulations that make the loans of the financial industry grow in line with total wages."

This is an example of how it is necessary to link banking supervision to public policies as a whole, a very practical issue: if wages do not grow in line with economy, the consequence is higher financial leverage for households to keep up spending, hence a more fragile financial situation. By the same token, the casualization of the labor market could increase financial fragility. Hence, a full employment policy could do more for financial stability than many prudential regulation tools could do. Before the crisis, this conclusion could be rejected as hopelessly démodé; now it is fairly widespread (for instance, Kumhof et al. [2015] and Jaumotte et al. [2015]).

In the Minskyan perspective, business cycles are basically investment cycles and investments are based on profits as "business profits are the key element in determining how well a capitalist economy works" (Minsky 1986b). The basic role of banking regulation and of public policies in general is to stabilize profits in order to help central banks preserve financial stability. This means that the once-again fashionable macroprudential supervision contains key elements for rebuilding an effective framework. The general trends impose themselves on single banks and other economic agents via the beauty contest. This principle has many effects.

First of all it helps to define the hierarchy of regulatory objectives. Financial stability is the most important and the others should be aligned to it. In particular, macroprudential supervision "is logically prior" to microprudential supervision (Alessandri and Panetta 2015).

Second, from this hierarchy also flows the efficient institutional design of authorities and regulatory tools. Before the crisis, a general financial crisis was ruled out, as central banks had learned the lesson of 1929 (Temin 1989; Bellamy Foster and Magdoff 2008). The institutional consequences of this conclusion, together with the victory of deregulation, was to create separate authorities to supervise banks and the financial 
system, like the British Financial Services Authority (Esposito 2005). Central banks pursued price stability, financial regulators prudential supervision, and that was it. Bank panic and lending of last resort were considered old tales that were irrelevant. Then banks started to collapse and things changed. As was particularly evident in the UK, authorities are not able to lend (as central banks can do), cannot change market sentiment, and are therefore useless during a crisis. It was also evident that central banking and supervision goals are largely overlapping because financial stability and price stability are connected. For instance, in assessing the S\&L debacle, Minsky (1994) noted that this was due to Volcker's policy of raising interest rates to fight inflation, which basically meant the end of their business model. This was not anticipated because no one considered monetary policy and banking supervision together. Another more recent example is the shortselling ban after the Lehman Brothers collapse. It was imposed on shares of too-big-tofail (TBTF) banks, but this shifted speculation towards small- and medium-sized banks, pushing the public to think that the authorities "protected the big guys and let the smaller ones fend for themselves" (Bair 2012). In general, monetary policy and banking supervision need coordination. As the Bank for International Settlements (BIS) (2011) observes: "Central banks must be involved in the formulation and execution of financial stability policy if such policy is to be effective." The original "twin peaks" model (central bank for monetary policy, an independent authority for banking supervision) is over (Masciandaro 2012). Microprudential supervision, either in the central bank or followed by another authority, is now less important than financial stability. Therefore, central banking is more important than banking supervision, with potential conflicts of interest between the two (Dabrowski [2016]; see also Boyer and Ponce [2010]). It is interesting that before the crisis this simple fact was ignored: central banks lend to banks, so they have more skin in the game in supervising them (just like any bank monitor its clients), as Minsky pointed out a quarter century ago (Wray [2015]; see also Bair [2012]).

Moreover, as far as regulatory capture is concerned, for lobbyists and government it is more difficult to capture a central bank with a printing machine and a trillion-dollar balance sheet than an authority that lives on fees or state transfer payments. Also on this issue, what matters is the "long-established and long-fostered corporate cultures that have 
helped to brace the institution against various forms of capture" (Masciandaro et al. 2013), that is central banking's tradition of independence.

The profound change is also true for supervisory tools: the idea that different goals require separate authorities is superficial. When the things get serious, lending of last resort is the only viable tool for stabilizing the situation. This is also linked to issues such as credibility (that is tradition) that are relevant during a panic situation, as Kay (2009) observed: "the Bank of England retains from that earlier time a prestige and authority which the Financial Stability Authority (FSA) is never likely to match. That prestige and authority is of some advantage in the exercise of regulatory functions." In the new situation it is clear that micro- and macroprudential supervision must be pursued by the same authority (Bayoumi et al. 2014) and, broadly speaking, systemic risk issues should be prominent in terms of analysis and supervisory tools. As prudential supervision tools are basically "micro" in nature (Onado 2012), this means a smaller role for prudential supervision.

The need to coordinate monetary policy and banking supervision also has consequences for central bank independence. Bayoumi et al. (2014) noted: "Independence is clearly still desirable with regard to price stability. But it may prove politically difficult under expanded central bank mandates." When financial fragility is widespread, independence changes meaning. The already-mentioned S\&L crisis is a glaring example of the fact that monetary policy cannot be independent from banking regulation. The coordination needs work both ways. For instance, a dysfunctional banking system cannot be used to attain monetary policy goals, as was too clear after the Lehman Brothers collapse. The new framework of monetary policy and banking supervision should be created accordingly.

\subsection{Tools of Supervision}

The new institutional framework of banking supervision is not the only aspect that amounts to a complete vindication of Minsky's ideas. This is also true for the tools of supervision. In fact, the conclusions we've reached so far can be seen in a number of measures and decisions made at the international level that depart from the light-touch, 
market-friendly approach dominating the fiscal landscape. In the Minskyan framework, microprudential supervision is simply a way to identify rotten apples; it cannot change the financial landscape. The classical tools of prudential supervision are generally good for that goal in the sense that they can effectively rank banks by risks, but this ranking cannot measure overall financial stability. Looking at specific prudential measures, there are two items that were generally overlooked before the crisis: liquidity and profitability. In Basel III they are back on the agenda.

Liquidity risk was largely ignored before the crisis and the business model of the banks incorporated the idea that liquidity was always on hand when needed. Banking regulators largely agreed. Ironically, long ago a banking regulator (the Office of the Comptroller of the Currency in 1966) contacted Minsky to develop regulatory tools based on the socalled cash flow-oriented bank examination (CFOS) process (see Minsky 1966, 1967) that puts liquidity center stage. The core message Minsky (1967) proposed is that "liquidity is not an innate attribute of an asset but rather liquidity is a time related characteristic of an ongoing, continuing economic institution." In this approach the link between micro and macro supervision is provided by liquidity: when a single bank is in trouble, liquidity is not an issue and prudential supervision can be effective; when many are, lending of last resort comes in. The assessment of a single institution by its regulator always comes with an implicit ceteris paribus clause on the state of the world: "Any statement about the liquidity of an institution depends upon assumptions about the behavior of the economy and financial markets. As the assumptions are changed, the estimate of the liquidity of the institutions will vary" (Minsky 1967).

Basing itself on liquidity risk, the CFOS is neither a micro nor a macro approach — it is both. It connects the supervision of banks, market infrastructures, markets, and all other participants in the system to central banking via lending of last resort. A last point on liquidity is that it is also linked to prudential ratios. The mainstay of prudential supervision is made by capital requirements, but, at the end of the day, a bank's capital is made by liquid assets. This means that the true situation of liquidity (i.e., the marketability of these assets) vastly affects the real capitalization of the banks. 
As far as a bank's profitability is concerned, before the crisis, higher profits meant better management (efficiency, innovation, and so on), but as it is now obvious that markets are not efficient, market results do not signal efficiency. The more profitable banks are the riskier banks. This simple truism is not accepted by banking regulation, although it is partially captured by the leverage ratio. This is another example of an old idea defended by Minsky until his death (Ryoo 2013), derided until reality had the last laugh. Already in 1972, Minsky warned that excessive leverage was a problem because "[ $[$ the drive for profits makes banks work at evading this constraint: i.e., banks want to increase this leverage ratio" (Kregel 2014).

Analyzing liquidity and profitability, Minsky (1967) pointed out the need to strengthen the "aggressiveness of the bank in seeking new business." This is because the profitstabilizing framework also helps to explain the relationship between innovation and regulation. Minsky and Campbell (1988: 6) explain:

\begin{abstract}
The normal, profit-seeking activities of agents lead to innovation in order to create new sources of profits; innovations can be in products, processes, or finance. The search for profits also drives agents to avoid, evade, and adapt to the structure of regulation and intervention put in place to constrain incoherence. In time this undermines the effectiveness of a regime of intervention that "stabilizes the unstable system." Therefore if regulation is to remain effective, it must be reassessed frequently and made consistent with evolving market and financial structures.
\end{abstract}

We noted that financial innovation is a way to avoid the path of declining profitability for mature sectors in the economy, therefore the "repeating stages of regulatory avoidance and reregulation" (Kane 1981) are an inevitable component of the financial landscape. The more regulated the industry, the more compelling the innovation. Of course, innovation allows the innovator a higher rate of profit, but the overall results are quite different. For instance, in the field of risk management, Brunnermeier and Sannikov (2014) point out: "Financial innovation that allows experts to hedge their idiosyncratic risk can be self-defeating, as it leads to higher systemic risk." 
The goal of financial regulation vis à vis innovation is to allow the positive development of new business, products, and services while avoiding the excesses of the bubble that comes with them (Kregel and Tonveronachi 2013). Minsky (1992a) stated: "[T]he function of regulation and supervision is to dominate the endogenous economic processes which make for incoherence once the financial commitments become such that the economy is fragile." It is worth noting the word he used to assess the role of authorities: they should dominate the processes. That is not exactly a light-tough approach. In fact, Minsky (1994) explains: "The regulatory and supervisory structure needs not only to adjust with the institutional and usage changes but also to guide the development of apt financial institutions." The state is not a detached analyst of financial innovation, therefore it should intervene to give orientation to operators, for instance in the field of market standards. Minsky was aware that a profit-maximization-based economy implies that regulation is always left behind: "[I]n a world of businessmen and financial intermediaries who aggressively seek profit, innovators will always outpace regulators." This was written in 1986, when much of the financial deregulation was still to come.

This means that regulation must act to push profits countercyclically. This is nothing new, as this is also how monetary policy works. If reregulation fails to stabilize profits it is useless. As Stephens (2011) put it: "[A]ny reform that does not significantly reduce bank profits in the medium to long term will have failed."

Innovation means a bubble and during a bubble financial euphoria also infects regulation. The neglect of systemic risk and macroprudential supervision before the crisis is part of this trajectory. Laissez-faire policies seemed justified by high profits. Herd behavior and the beauty contest hold sway for good, at least in mainstream media and economic literature. Then, all of a sudden the bubble explodes, banks implode, and lender of last resort comes into play as banks' profits go down and they need to be saved by public funds. Reregulation ensues. This means that the crackdown starts precisely when profits are collapsing on their own, forcing policies to rescue profitability one way or another. At the end of the day, this confirms that regulation has the main duty of regulating profits. However we face a trade-off here. As we have seen, innovation rapidly leaves regulation 
behind; hence a frequent reassessment of banking regulation is vital. The point is that a reassessment during the bubble will follow this trend, resulting in light-touch regulation, as was the case before the crisis. We would need regulation that is able to resist the bubble, one that is tough exactly when the things are going well, which is very difficult to attain with prudential supervision. This is one of the main reasons for what we will propose.

Another consequence of the need for frequent regulatory updating is that the relative importance of rules and principles should change. There is a long-standing debate about the merits of rule-based versus principles-based supervision. Needless to say, rules are rapidly outgrown by innovation. On the contrary, core principles are basically always valid. So banking supervision should be based on principles - such as the core principles of the Basel Committee (2012) - more than on detailed rules that should be changed continuously.

What we have seen so far explains why prudential regulation is not very effective for maintaining financial stability. It also explains why banking regulation is intrinsically connected to lending of last resort. Tools like deposit insurance are therefore much more important than prudential ratios during the crisis.

\subsection{Structural Supervision and Diversity}

A drawback of a regulatory framework based on prudential supervision tools is that, together with concentration, it reduces diversity. This seems counterintuitive, as bigger banks are more diversified, but as Haldane (2010) explains:

[I]f all banks are fully diversified and hold the market portfolio, that means they are all, in effect, holding the same portfolio. All are subject to the same systematic risk factors. In other words, the system as a whole lacks diversity. Other things equal, it is then prone to generalized, systemic collapse. Homogeneity breeds fragility.

Basel II pushed the banks to become more and more similar in terms of their business model and risk management, so when the crisis struck, there were not one hundred big 
banks or even a dozen, but basically a single operator: prudential supervision nurtured herd behavior.

It is now clear that regulation should be oriented to favor diversity, aiming at "policies that defeat the SIFI monoculture" (Varoufakis 2013), but how do we achieve this result? An idea could be to help small banks by creating a network of local community development banks. As Wray (2011b) explains: "[R]eforms ought to aim for downsizing. This does not necessarily mean a return to Glass-Steagall separation by function, but it does mean that policy should favor small institutions over large ones." This is right but is a very slow way to rebalance the market against TBTF banks. Banking regulation should take into account the need to defend diversity and small operators. This means reducing the weight on the "proportionality principle" of Basel II, which amounts to a double standard where big banks are carefully monitored and small ones are left alone and cannot aspire to compete with SIFIs.

As international supervision pushed big banks towards herd behavior, one can ask if harmonized regulation is good. Moosa (2010: 197) observes: "one way forward is to forget about the international harmonization and unification of banking regulation and to leave every country to formulate its own regulation." This would be a radical break with the policies of the last 30 years or so. The simple fact that international regulation is put under scrutiny is a demonstration of how the crisis changed things. Relying more on structural supervision that is eminently un-international is a way to do it. But structural supervision also has also another beneficial feature. Defending the Glass-Steagall Act, Minsky (1995) explained: "it was not so much the differences in riskiness as it was the ease of understanding the operations that led to the separation of investment and commercial banking." In other words, it is paramount to have regulation in place that is easy to understand and apply. Prudential supervision is more difficult to bend to this aim. 


\section{REREGULATION WILL NOT SOLVE LONG-TERM ISSUES: THE MINSKYAN ALTERNATIVE}

As always, the end of the bubble and the crisis pushed for a reconsideration of banking regulation. The proposals go in the right direction, and yet they will not change anything important. There is an unmistakable indicator of the fact that regulatory reforms were not effective: Wall Street. After the crash of 1929, the Dow Jones took more than 25 years to regain its pre-crash level; this time it only needed five years. This means banks are not very impressed by the crackdown, and for good reason.

Capital requirements, business conducts standards, and so on have been tightened, and yet the core issue has not been touched. Big banks still rule the world economy. Indeed the domination is even stronger than before the crisis, as they are bigger and more concentrated. A specific regulation on globally systemically important institutions (GSIIs or SIFIs) is now more or less in place: they pay higher capital requirements and receive more attention from their regulators (as can be seen by the hefty fees they paid for different reasons), but with no strong effects on their business model and, again, their share prices show that markets are not very frightened by all this attention.

We think the markets are right. They are not impressed because the measures that have been put in place to rein in big banks are not decisive. In fact, as Wray (2011b) wrote: "Hyman Minsky would not be impressed." The issue here is not higher capitalization, better risk-management procedures, efficient living wills, or so on. The main problem of the world financial system nowadays is the disproportionate power of the banks vis à vis the governments, resulting in bigger and bigger banks, and weaker and weaker governments. The very existence of SIFIs is tantamount to a subordination of public policies to their needs. They are like giant black holes, so powerful and concentrated that the very fabric of the space around them is completely distorted and bent. This disturbing truth is hardly an original idea. For instance, Roubini and Mihm (2010) observe on TBTF banks: "Frankly, they shouldn't exist — at the very least, they should be pushed to break 
themselves up." Many others made similar remarks. ${ }^{11}$ Even the IMF (2010) proposed limits on market share or asset size, proposing to add caps on market share to additional capital requirements and leverage ratios. Before we enter into the concrete proposals to tackle the issue, we will discuss why it is so important.

\subsection{Why Too Big to Fail Banks Are the Main Problem}

Too big to fail [...] is the single most important policy issue that has emerged from the crisis. - S. Cecchetti (2011)

There are many reasons why the existence of SIFIs is a problem. The first issue is their sheer political power. If we look at other episodes of the antitrust battle between public institutions and big companies we see that the main issue at stake was their political power. This was the case, for instance, behind Teddy Roosevelt's trust-busting campaign (Stiglitz 2010). This is also the case now as Johnson (2009) wrote: "Oversize institutions disproportionately influence public policy; the major banks we have today draw much of their power from being too big to fail" (see also Dimsky [2010]; Kregel [2014]). Their power is also visible from the advantage they have in regulatory and tax arbitrage (Blundell-Wignall and Atkinson 2010).

A second point is that limiting the power of TBTF institutions also allows for a reduction in the overall size of the financial sector. Of course this is a positive goal only if one considers that "the success of the financial sector is not an end in itself, but a means to an end" (Bair 2012: 313). If before the crisis the growth of finance was considered unilaterally good, now many are aware that a nation can have too much finance (Arcand et al. 2012). ${ }^{12}$ Stiglitz commented: "We had too big of a financial sector. In the postcrisis era, the financial sector as a whole will shrink" (Stiglitz et al. 2009). This is linked to innovation because as we noted, innovation yields growth in the size of the financial sector. The OTD model has proven this point: the size of finance is not business-model

\footnotetext{
${ }^{11}$ See, for instance, Johnson (2009); Stiglitz (2010); Moosa (2010); Johnson and Kwak (2010); R. Fisher (2013); Polouček (2013); former central bankers, such as, Bernanke, King, and Volcker have also made similar remarks.

${ }^{12}$ It is worth noting that in this work finance starts having a negative effect on economic growth when credit to the private sector reaches $100 \%$ of GDP, a fairly common level.
} 
independent.

Thirdly, there is a question of market distortion. SIFIs are heavily subsidized by the states, and hence have an unfair competitive advantage. For instance, Brewer and Jagtiani (2011) find a subsidy of between $\$ 15$ billion and $\$ 23$ billion for the eight mergers of more than $\$ 100$ billion in the US in the period 1991-2004. Haldane (2010) observes that "[f]or UK banks, the average annual subsidy for the top five banks [...] was over $£ 50$ billion - roughly equal to UK banks' annual profits prior to the crisis. At the height of the crisis, the subsidy was larger still." Siegert and Willison (2015) collect all the studies on this issue, finding a wide range of funding cost advantages (17-80 basis points for deposits, up to 80 basis points for bonds). As we have seen, a source of unfair advantage is (paradoxically) reregulation, because more complex legislation is more costly to be compliant with and TBTF banks can manage it more easily. Regulatory complexity is a danger in itself. Haldane (2012) noted: "the more complex the environment, the greater the perils of complex control" (see also Minsky [1995]; Caprio [2013]).

We should also add that the problem is growing. In 1984 when the TBTF acronym was created, in the US alone there were 11 such banks. Nowadays globally, the banks considered to be systemically important by international regulators number less than 30 .

\subsection{What to Do: A Global Cap to Solve the Problem}

The private market power of giant corporations must be broken. - H.P. Minsky (1982b) There is a wide consensus (but not unanimity, as we will see) that TBTF banks are a problem. It is also generally acknowledged that prudential regulation cannot solve this issue. The solution everyone has in mind is to have smaller banks. For instance, the Governor of the Dallas Fed, Richard W. Fisher, (2013) commented: “The solution for ending 'too big to fail' is not bigger government but smaller, unsubsidized banking institutions governed by the market discipline of creditors at risk of loss." And Johnson (in Stiglitz et al. 2009) noted: "Ideally, big banks should be sold in medium-sized pieces, divided regionally or by type of business, to avoid such a concentration of power." It is clear that to achieve this goal a size cap should apply. We have an example of this cap in 
the US market, as Goldstein and Veron $(2010)^{13}$ remind us:

The Dodd-Frank Act of 2010 specifies that any insured depository or systemically important nonbank be prohibited from merging or acquiring substantially all the assets or control of another company if the resulting company's total consolidated liabilities would exceed 10 percent of the aggregate consolidated liabilities of all financial companies. This liability size-cap would not require any existing US financial institutions to shrink, though, and does not prohibit their organic growth in the future. It parallels and complements a preexisting cap of 10 percent of total domestic deposits that cannot be exceeded by some forms of external growth, introduced by the RiegleNeal Interstate Banking and Branching Efficiency Act of 1994.

What is needed is a structural measure that cannot be softened later on, that is simple to understand, and easy to enforce on a worldwide scale. Moreover, the measure should be business-model independent (the Volcker rule or Vickers reporting ring-fencing are not). We think the size cap should give the banks the most choice on how to break themselves up. The GDP-based size cap is a good start but has a problem: it cannot be applied internationally without giving US banks an unfair advantage. Our alternative is the following.

\section{A Global Cap (GC) Rule}

International regulators (for instance the Basel Committee on Banking Supervision) issue the following size-cap rule: A bank cannot have total assets of more than 250 billion in special drawing rights (SDR) (amounting to $€ 310$ billion and $\$ 350$ billion at the date of writing) ${ }^{14}$ The cap will be increased by 5 billion in SDR a year. The cap is in absolute values (not risk weighted) and applies at the group level. The banks are given a period (say two years) in which to adjust their balance sheets to the rule or to choose how to divide themselves up to comply with the cap.

The main advantages of the GC are as follows.

First of all, the problem is solved. TBTF banks rapidly disappear for good. Contrary to prudential supervision or even to structural measures like the Volcker rule, this rule cannot be softened, as banks will be broken up and this means they will start to develop

${ }^{13}$ See also Powell (2013) and Ötker-Robe et al. (2011).

${ }^{14}$ Singh (2013) proposes a cap of $\$ 1$ trillion, which we consider too big. A number of scholars and central bankers raised similar ideas (see http://www.toobighasfailed.org/too-big-to-fail/). 
as separate entities, therefore vastly increasing competition. Moreover, as governments remain the same, to a large extent the balance of power is pushed away from the big banks.

Secondly, differently from the Glass-Steagall Act or the Volcker rule, the GC does not decide how the banks should be organized, nor does it have an implicit hypotheses on the different riskiness of business models or sectors. It is up to the banks to decide how they want to operate in terms of geographical reach, sectors, and so on. This helps to increase and maintain their diversity, a key feature for financial stability. This also reduces their connection as banks become more and more diverse. Systemic risk is therefore reduced, both directly and indirectly.

Thirdly, as Haldane (2012) pointed out, "[t]he move to internal models [...] has resulted in a ballooning in the number of estimated risk weights. For a large, complex bank, this has meant a rise in the number of calculations required from single figures a generation ago to several million today." This means that Basel II and Basel III make many implicit assumptions about how asset classes are priced, correlated, risk weighted, and so on. The GC makes none.

Fourthly, it is the simplest and most transparent rule conceivable. It is not prone to arbitrage or interpretation or national biases. It also allows for the elimination of many other rules (basically all the rules on SIFIs and many of the prudential rules). This is not trivial. It has been estimated that the compliance costs of Basel III for a midsize European bank are equivalent to a 200 full-time jobs. This translates into over 70,000 new full time jobs for the industry (Haldane 2012). There are more efficient ways to use these resources. Hence, using the GC in place of a detailed compliance regulation will rebalance the regulatory framework against big banks.

Finally, the GC allows banks' organization to become less complex and easier to manage and supervise. As for risky behavior by top management, their bonuses are linked to the bank's size and to its growth. Given that a bank's size cannot increase forever, their 
business model is not molded on a policy of growth at all costs.

We will now touch on some objections to the GC and why we think they can be overturned.

\subsection{Objections to a Global Cap}

A first objection concerns efficiency. Anti-antitrust supporters always noted the power of scale economies in reducing prices and increasing consumers' welfare. Now, there are many studies on scale economies in the banking sector; most of them find scale economies completely deployed at a very small size. For instance, Gambacorta and van Rixtel (2013) cite 12 studies on the issue and, apart from one study, the biggest optimal size found is $\$ 50$ billion (on the issue see also Berger et al. [1999]; Haldane [2010]; Ötker-Robe et al. [2011]; Laeven et al. [2014]).

However, this conventional wisdom was overturned by recent studies. In particular, Hughes and Mester (2011) and Wheelock and Wilson (2012) found strong scale economies at any size. This has a dramatic impact on costs: "[O]ur back-of-the-envelope estimate suggests that capping the size of the four largest bank holding companies at $\$ 1$ trillion would result in an increase in the total cost of operating those firms that would exceed their combined profits in each of the four years 2003-06" (Wheelock and Wilson 2012). All in all they found major costs of around $\$ 80$ billion a year. This seems like a big number, but we should consider the \$14 trillion needed to save US and EU banks after 2008 (Haldane 2009a). Even if we split the bill in two (excluding Europe), this is almost 90 times the major costs found by Wheelock and Wilson for 2003-06. The GC seems like a good deal for taxpayers after all. However, this is exactly the point. Is it possible that there are positive externalities in big banks but they all end up in the pockets of shareholders and top managers while negative externalities in terms of systemic risk are paid by all? So, "[t]he benefit from larger scale must be balanced against the increased risk to the financial system and the increased risk of political/regulator capture that comes with size and power" (Powell 2013). In fact, what kind of efficiency is provided by big banks? The same authors state: "Although our approach can provide 
information about the extent of cost economies in banking, it does not address such questions as whether increased bank scale affects the costs incurred by bank customers, the risks incurred by banks, or the risks that the banking system may impose on society more broadly."

Exactly our thoughts. As Laeven et al. (2014) noted when analyzing those papers: "Large banks are riskier than smaller ones." Data prove the point conclusively. For instance: "In the course of the crisis, more than two-thirds of the 100 leading banks worldwide received state support" (FSB 2011a). This is a strange efficiency indeed. If size helped the diversification of risks, big banks would have been the strongest during the crisis. This was not the case and it is also speaks to the idea that dismantling big banks can be rejected as "disproportionate" (FSB 2011a).

However, there is another consideration that can easily overturn the infinite scale efficiency argument. If we take the car industry as an example, we find that there are no small players (excluding very specific segments of no general interest, say, ultra-luxury cars). This is because scale economies are a structural feature of the sector. On the contrary, although big banks are heavily subsidized by the states, have cost advantages, and so on, there are small and medium banks that survive nicely. This would be impossible if scale economies were so overwhelming.

There is a third important counterobjection. Efficiency is good if the outcome of the productive process is socially positive. For instance, we cannot deny that the mafia is more efficient than a single drug pusher, but is it good for society? The problem is that "[m]ost of what the financial sector is now doing is actually harmful" (Wray 2011b). A discussion about banks' efficiency cannot overlook this aspect.

A second objection to the GC is that it could stifle innovation. Now, it has been noted that: 
[A] disproportionate part of the innovations in our financial system were aimed at tax, regulatory, and accounting arbitrage. They did not produce innovations which would have helped our economy manage some critical risk better, like the risk of home ownership. In fact, their innovations made things worse. (Stiglitz et al. 2009)

Moreover, data suggests that innovation is made by firms of all size. Thirdly, the GC forces banks to specialize in a certain area of business and this can foster specialization and innovation (Avgouleas 2015).

Another and more compelling issue is political feasibility (Stiglitz 2010). For instance, the former Chairman of the FDIC, Sheila Bair (2012: 327), observed: "Though I'm sympathetic to that viewpoint, I do not believe Congress has the political will to take that step." This was true also for deposit insurance in 1933. Even Franklin Roosevelt was frightened by the US banks' opposition to it, but he had the political courage to stand his ground (Greider 1987). A similar objection is that "any such measure would need to be internationally coordinated and this is unlikely in practice" (Llewelyn 2013: 375). But what about Basel II or Basel III? They are regulations of immense complexity and yet they have been agreed to at the international level. By the same token, objections based on the fact that a size cap "may be imprecise and difficult to implement" (Laeven et al. 2014) are not impressive. How much more complex and difficult to implement is Basel III? And yet...

A fourth issue (linked to scale economies) is that international groups have centralized key functions (CEBS 2010) that should be divided after a break up, but it is not clear how that should be accomplished. The answer is that banks are very good at finding ways to cut costs, so they will adopt a consortium model or a part of the former big bank will become a firm specialized to offer IT and other services to the other banks, just like the current case of custodian banks, cash management operators, and so on. Sharing services and clients among banks (think about syndicated loans) is also the answer to the objection that big banks are needed to serve big clients. 
A fifth aspect is linked to time inconsistency. Would a GC resist a big bank crisis? For instance, the Riegle-Neal Interstate Banking and Branching Efficiency Act of 1994 has been waived to allow for emergency mergers (Johnson and Kwak 2010). However, the possibility of an emergency merger can be solved by breaking up the failing entity, something that happens often, even now.

A sixth remark is based on the state/bank relationship. It seems that to rebalance it, Minskyan "big government" proposals are needed. In reality, the smaller the big banks, the smaller the state budget must be to have financial and political balance. So a GC is the necessary precondition for a political choice about how much public money to spend and what to spend it on; however, as long as TBTF banks dominate the financial landscape, there is no choice.

Other objections are that there are concentrated systems that did not fail (Goldstein and Veron 2010) and conversely that systems made by small and medium banks can fail, too (the so-called "too-many-to-fail" issue) (Fischer 2014). In other terms, since banks of all types failed, there is no point in singling out the big ones (Llewelyn 2013). We think these are not convincing objections. It is true that all dogs can bite, but you can feel the difference if it is a bull mastiff that bites you instead of a Chihuahua:

SIFIs are a different kind of bank in terms of systemic risk and "interconnectedness." Dozens of small banks can fail with no significant increase in the probability of default of others, but a single mega bank's demise is enough to shake the other big banks and the entire system. While for a small- and medium-sized intermediary what matters most is the average situation of its competitors, for SIFIs what really matters is the situation of the worst among them. Small banks are like a colony of penguins: even if many of them are killed, the colony survives. SIFIs are like a group of climbers roped together, if one falls, the others follow. The very existence of a SIFI is a negative externality for other SIFIs and for the entire world. The problem is getting worse, since this externality is often internalized through M\&As [mergers and acquisitions], creating a dwindling number of ever larger conglomerates. A tool is needed to address this basic contradiction. (Esposito 2013) ${ }^{15}$

\footnotetext{
${ }^{15}$ In this work there is an analysis of the main measures taken to tackle (not effectively) the problem of TBTF banks and a proposal to force them to share their fate (the "SIFI stability fund").
} 
All in all, we think objections to a size cap are not unassailable, while the effects it would have on the financial landscape are pervasive and decisive.

\section{CONCLUSIONS}

Non son li editti etterni per noi guasti. (The eternal edicts are not void through us.)

— Dante (1920)

The crisis shattered the conventional wisdom about how financial markets work and how to regulate them. Authorities intervened to stop the panic based on pragmatism, which represented an implicit rejection of mainstream economics. This is also what happened in the 1930s, as "the essential reforms of the United States' financial system predate The General Theory" (Minsky 1992a). However, the very success in taming the collapse reduced the efforts to radically change the business model of the big banks.

In this work we have tried to explain the main trends of the financial system and their effects on banking regulation. We also underlined the good and the bad of reregulation and, above all, its main paradox: if reforms do not change banks' behavior, hence their profitability, they are useless. If they do, they will push them toward financial innovation to remedy the downtrend. Therefore a pessimistic conclusion could arise: banking regulation is either useless or self-defeating. Is there any alternative to this conclusion?

Minsky (1992a) observed that "[s]upervision and regulation are ways to protect the government against the call of the Treasury." In other words, at its best, a banking regulator can be compared to the Greek mythological character Sisyphus, with the regulation taking the place of the rock: just when it is at its maximum height, the profit needs of banks inflates a bubble and throws the rock (regulation) down the hill. So the authorities have the goal "to delay the onset of instability and to contain the effects of instability" (Minsky 1992a). This metaphor illuminates the theory and practice of banking regulation. The rock will inevitably fall down, but it can be a huge avalanche or the fall of small stones. 
Our proposal changes this Sisyphean work because the GC is the only regulatory tool that can radically transform market concentration. Its application would amount to transforming Sisyphus' gigantic rock into a bunch of pebbles. The alternative is to leave big banks to transform the world economy into pebbles again. As Rosemblum (2011) observed: "The ultimate destination — an economy relatively free from financial criseswon't be reached until we have the fortitude to break up the giant banks." Although the GC seems radical or intrusive, in reality it is less intrusive than basically any other structural or prudential tool because it only rewinds the tape of the history as far as the size of banks is concerned. Thus, in reality, it is the most pro-competition measure available.

At any rate, we don't want to seem as though we are sharing the hubris of Sisyphus, so we do not reduce the needs of banking supervision to a GC. However, the other goals cannot be achieved without this precondition. In particular, there are three aspects we would like to highlight.

The first is the need for stronger diversity in the banking system, a paramount issue that is intractable as long as big banks are interested in converging towards the same business model. No specific prudential tool can remediate this issue and structural measures like the Volcker rule do not push for more diversity. The call of Minsky and others for a bigger role for local community development banks (Minsky et al. 1993) is theoretically and practically right. The question is that presently they cannot compete fairly with big banks. Cooperative banks are like mammals during the Jurassic period, existing at the fringe of the ecosystem. They needed the extinction of dinosaurs in order to start becoming important.

The second point is short-termism. Big banks want to grow because this means more money for shareholders and the top management. Their business model is based on immediate results in term of profits, whatever it implies later on. Short-termism and bubble seeking is perfectly rational for them. To align CEOs' incentives and incentives beneficial to society as a whole, this thirst for growth should be phased out. If the 
regulatory framework is not able to change the way banks maximize their profitability (i.e., to drive banks towards a different conception of what credit is and what their responsibility towards their communities is), it is ineffective.

The third point is ownership. Before the crisis, publicly owned banks were considered relics of the past and emerging economies were asked to follow the good example of advanced countries (i.e., to privatize) (Hawkins and Mihaljek 2001). Now the situation is more balanced. However, the formal ownership of the banks does not change per se how they behave, as an analysis of what happened after 2008 to nationalized banks can show. The issue is a different mission for them based on the idea of using the public part of the banking sector to maintain stability and to foster economic growth instead of increasing profitability as a goal in itself (Brown 2014). But even with public banks, in order to give them orders (and not wind up taking orders from the banks), the state should have the upper hand. This is very difficult when the bank has a balance sheet with a size comparable to the state's GDP itself. There is also, of course, an issue of a level playing field with privately owned banks. For these reasons, even a different distribution of ownership between public and private cannot substitute for a GC. Big banks, public or private, are TBTF entities.

Putting these three points together we can state that a GC is a necessary step toward reconceptualizing banking as having a strong responsibility to the public sector. As Brown (2014) observes: “[M]oney and credit are not market goods, but economic infrastructure, just as roads and bridges are physical infrastructure." Mainstream theory tries to capture this feature via systemic risk analysis and banking regulation via macroprudential supervision, but much more is at stake.

To reuse the biological metaphor that we used before, a global cap would be like a big asteroid hitting the planet, wreaking havoc on the banks presently ruling the world economy, but a positive shock for the rest of us. 


\section{REFERENCES}

Acharya, V.V., L.H. Pedersen, P. Thomas, and M. Richardson. 2010. "Measuring Systemic Risk." Federal Reserve of Cleveland Working Paper No. 1002. Cleveland, OH: Federal Reserve Bank of Cleveland.

Admati, A., and M. Helwigg. 2013. Bankers' new clothes. Princeton NJ: Princeton University Press.

Alesina, A., and A. Stella. 2011. "The politics of monetary policy.” In B. Friedman and M. Woodford (eds.), Handbook of Monetary Economics, Vol. 3B. Amsterdam: North Holland.

Alessandri, P., and F. Panetta. 2015. "Prudential policy at times of stagnation: a view from the trenches." Quaderni di Economia e Finanza della Banca d'Italia No. 300. Available at: https://www.bancaditalia.it/pubblicazioni/qef/20150300/QEF_300_15.pdf?language_id=1.

Allen, F., and D. Gale. 2004. "Competition and Financial Stability." Journal of Money, Credit \& Banking 36(3): 453-80.

Allen, F., E. Carletti, and R. Marquez. 2011. "Credit Market Competition and Capital Regulation.” The Review of Financial Studies 24(4): 983-1018.

Alvaredo, F., A.B. Atkinson, T. Piketty, and E. Saez. 2013. "The Top 1 Percent in International and Historical Perspective.” NBER Working Paper No. 19075. Cambridge, MA: National Bureau of Economic Research. Available at: www.nber.org/papers/w19075.

Amato, M., and L. Fantacci. 2012. Fine della finanza. Rome: Donzelli.

Arcand, J., E. Berkes, and U. Panizza. 2012. “Too much finance?” IMF Working Paper No.12/161. Washington, DC: International Monetary Fund. Available at: www.imf.org/external/pubs/ft/wp/2012/wp12161.pdf.

Arnold, B., C. Borio, L. Ellis, and F. Moshirian. 2012. "Systemic risk, macroprudential policy frameworks, monitoring financial systems and the evolution of capital adequacy." Journal of Banking \& Finance 36(12): 3125-32.

Atkinson, A.B., and S. Morelli. 2015. "Inequality and Crises Revisited." Economia Politica 32(1):31-51.

Avgouleas, E. 2009. "The Global Financial Crisis, Behavioural Finance and Financial Regulation: In Search of a New Orthodoxy." Journal of Corporate Law Studies 9(1): 23-59. 
Avgouleas, E. 2015. "Bank Leverage Ratios and Financial Stability: A Micro- and Macroprudential Perspective.” Levy Economics Institute Working Paper No. 849. Annandale-on-Hudson, NY: Levy Economics Institute of Bard College.

Bair, S. 2012. Bull by the horns. New York: Simon and Schuster.

Bank of England (BoE). 2010. Financial Stability Report, June. London: Bank of England. Available at: www.bankofengland.co.uk/publications/Documents/fsr/2010/fsrfull1006.pdf.

Bank for International Settlements (BIS). 2009. 79th Annual Report. Basel: Bank for International Settlements. Available at www.bis.org/publ/arpdf/ar2009e.htm.

Bank for International Settlements (BIS). 2010. 80th Annual Report. Basel: Bank for International Settlements. Available at: www.bis.org/publ/arpdf/ar2010e.htm.

Bank for International Settlements (BIS). 2011. 81st Annual Report. Basel: Bank for International Settlements. Available at: www.bis.org/publ/arpdf/ar2011e.htm.

Basel Committee on Banking Supervision (BCBS). 1996. Amendment to the Capital Accord to incorporate Market Risk. Basel: Basel Committee on Banking Supervision. Available at: www.bis.org/publ/bcbs24.pdf

Basel Committee on Banking Supervision (BCBS). 2012. Core Principles for Effective Banking Supervision. Basel: Basel Committee on Banking Supervision. Available at: http://www.bis.org/publ/bcbs230.pdf.

Basel Committee on Banking Supervision (BCBS). 2015. Finalising post-crisis reforms: an update. Report to G-20 Leaders. Basel: Basel Committee on Banking Supervision. Available at: www.bis.org/bcbs/publ/d344.pdf.

Battiston, S., D. Delli Gatti, M. Gallegati, B. Greenwald, and J.E. Stiglitz. 2012. "Liaisons Dangereuses: Increasing Connectivity, Risk Sharing and Systemic Risk." Journal of Economic Dynamics \& Control 36(8): 1121-41.

Bayoumi, T., G. Dell'Ariccia, K. Habermeier, T. Mancini-Griffoli, F. Valencia, and an IMF Staff Team. 2014. "Monetary Policy in the New Normal." IMF Staff Discussion Note 14/3. Washington, DC: International Monetary Fund. Available at: www.imf.org/external/pubs/ft/sdn/2014/sdn1403.pdf.

Bellamy Foster, J., and F. Magdoff. 2008. "Financial Implosion and Stagnation, Back To the Real Economy." Monthly Review 60(7): 1-29.

Bellino, E. 2010. "Employment and Income Distribution from a Classical-Keynesian Viewpoint.” Working Paper No. 3. Rome: Centro Ricerche Piero Sraffa. 
Bellofiore, R., and P. Ferri. 2001. Financial Keynesianism and market instability: the economic legacy of Hyman Minsky, Vol. 1. Cheltenham, UK: Edward Elgar.

Berger, A., R. Demsetz, and P. Strahan. 1999. "The Consolidation of the Financial Services Industry: Causes, consequences, and implications for the future." Journal of Banking and Finance 23(2-4): 135-94.

Berger, A.N., L.F. Klapper, and R. Turk-Ariss. 2008. "Bank Competition and Financial Stability." World Bank Policy Research Working Paper No. 4696. Washington, DC: World Bank. Available at: wwwwds.worldbank.org/servlet/WDSContentServer/WDSP/IB/2008/08/20/00015834 9_20080820103955/Rendered/PDF/WPS4696.pdf.

Bernanke, B. 2014. La Federal Reserve e la crisi finanziaria. Milano: Il Saggiatore.

Better Markets. 2012. "The Cost of Wall Street-caused Financial Collapse." Report from Better Market, September, 15. Available at: http://bettermarkets.com/sites/default/files/Cost $\% 200 f \% 20$ The\%20Crisis_2.pdf.

Bijlsma, M., J. Klomp, and S. Duineveld. 2010. "Systemic risk in the financial sector. A review and synthesis." Centraal PlanBureau Document n. 210. Den Haag: Centraal PlanBureau.

Blanchard, O., G. Dell'Ariccia, and P. Mauro. 2010. "Rethinking Macroeconomic Policy." IMF Staff Position Note 10/03. Washington, DC: International Monetary Fund. Available at: www.imf.org/external/pubs/ft/spn/2010/spn1003.pdf.

Blinder, A.S. 2010. "It's Broke, Let's Fix It: Rethinking Financial Regulation." International Journal of Central Banking 6(4): 277-330.

Blundell-Wignall, A., G. Wehinger, and P. Slovik. 2009, "The Elephant in the Room: The Need to Deal with What Banks Do." OECD Journal of Financial Market Trends, No. 2009/2. Paris: Organisation for Economic Co-operation and Development. Available at: www.oecd.org/finance/financialmarkets/44357464.pdf.

Blundell-Wignall, A., and C. Roulet. 2013. "Business models of banks, leverage and the distance-to-default." OECD Journal of Financial Market Trends, No. 2012/02. Paris: Organisation for Economic Co-operation and Development. Available at: https://www.oecd.org/finance/BanksBusinessModels.pdf.

Blundell-Wignall, A., and P.E. Atkinson. 2010. "Thinking Beyond Basel III: Necessary Solutions for Capital and Liquidity.” OECD Journal of Financial Market Trends, No. 2010/01. Paris: Organisation for Economic Co-operation and Development. Available at: http://www.oecd.org/finance/financial-markets/45314422.pdf. 
Bolt, W., and A.F. Tieman. 2004. "Banking Competition, Risk, and Regulation." IMF Working Paper No. 04/11. Washington, DC: International Monetary Fund. Available at: www.imf.org/external/pubs/ft/wp/2004/wp0411.pdf.

Boot, A.W., and M. Marinč. 2007. "Competition and Entry in Banking: Implications for Stability and Capital Regulation." CEPR Discussion Paper No. 5518. Washington, DC: Center for Economic Policy and Research.

Borio, C., and K. Tsatsaronis. 2005. "Accounting, prudential regulation and financial stability: elements of a synthesis.” BIS Working Paper No. 180. Basel: Bank for International Settlements. Available at: http://www.bis.org/publ/work180.pdf.

Borio, C. 2012. "The financial cycle and macroeconomics: what have we learnt?" BIS Working Paper No. 395. Basel: Bank for International Settlements. Available at: http://www.bis.org/publ/work395.pdf.

Boyd, J.H., G. De Nicolò, and A.M. Jalal. 2006. "Bank Risk-Taking and Competition Revisited: New Theory and New Evidence.” IMF Working Paper No. 06/297. Washington, DC: International Monetary Fund. Available at: www.imf.org/external/pubs/ft/wp/2006/wp06297.pdf.

Boyer, P., and J. Ponce. 2010. "Central Banks Regulatory Capture and Banking Supervision Reform.” Documento de Trabajo 003-2010. Montevideo: Banco Central del Uruguay. Available at: http://www.bcu.gub.uy/Estadisticas-eIndicadores/Documentos\%20de\%20Trabajo/3.2010.pdf.

Boz, E., and E.G. Mendoza. 2010. "Financial Innovation, the Discovery of Risk, and the U.S. Credit Crisis." NBER Working Paper No. 16020. Cambridge, MA: National Bureau of Economic Research. Available at: www.nber.org/papers/w16020.

Brancaccio, E., and G. Fontana. 2011. "The Conventional Views of the Global Crisis: A Critical Assessment." In P. Arestis, R. Sobreira, and J.L. Oreiro (eds.), The Financial Crisis: An Assessment of the Global Impact of the Financial Crisis. Basingstoke, UK: Palgrave Macmillan.

Brei, M., L. Gambacorta, and G. von Peter. 2011. "Rescue Packages and Bank Lending.” BIS Working Paper No. 357. Basel: Bank for International Settlements. Available at: www.bis.org/publ/work357.pdf.

Brewer, E., III, and J. Jagtiani. 2011. "How Much Did Banks Pay to Become Too-Bigto-Fail and to Become Systemically Important?" Federal Reserve Bank of Philadelphia Working Paper No. 09-34. Philadelphia: Federal Reserve Bank of Philadelphia. Available at: www.philadelphiafed.org/research-anddata/publications/working-papers/2011/wp11-37.pdf. 
Brown, E. 2014. “The Public Bank Solution.” Binzagr Institute for Sustainable Prosperity Policy Note 101. Granville, OH: Binzagr Institute for Sustainable Prosperity. Available at: www.binzagr-institute.org/policy-note-101/.

Brunnermeier, M.K., A. Crocket, C. Goodhart, A.D. Persaud, and H. Shin. 2009. The Fundamental Principles of Financial Regulation (Geneva Reports on the World Economy). Geneva: International Center for Monetary and Banking Studies.

Brunnermeier, M.K., and Y. Sannikov. "A Macroeconomic Model with a Financial Sector." American Economic Review 104(2): 379-421.

Caballero, R.J., and A. Krishnamurthy. 2007. "Collective Risk Management in a Flight to Quality Episode.” NBER Working Paper No. 12896. Cambridge, MA: National Bureau of Economic Research. Available at: http://www.nber.org/papers/w12896.

Calomiris, C.W., and R.J. Herring. 2013. "How to Design a Contingent Convertible Debt Requirement That Helps Solve Our Too-Big-to-Fail Problem." Journal of Applied Corporate Finance 25(2): 39-62.

Calomiris, C.W., and S.H. Haber. 2014. Fragile by Design. The Political Origins of Banking Crises \& Scarce Credit. Princeton, NJ: Palgrave Macmillan.

Caprio, G., Jr. 2013. "Financial Regulation After the Crisis: How Did We Get Here, and How Do We Get Out?" London School of Economics and Political Science Special Paper No. 226. London: London School of Economics and Political Science. Available at: www.lse.ac.uk/fmg/workingPapers/specialPapers/PDF/sp226.pdf.

Carré, E., and M. Gauvin. 2015. "Financial Crisis: The Capture of Central Banks by the Financial Sector?” Mimeo, Université de Bretagne Sud.

Caverzasi, E. 2013. “The Missing Macro Link.” Levy Economics Institute Working Paper No. 753. Annandale-on-Hudson, NY: Levy Economics Institute of Bard College.

Cecchetti, S.G. 2011. "How to cope with the too-big-to-fail problem?" 10th Annual Conference of the International Association of Deposit Insurers, Warsaw, Poland, October 19.

Cecchetti, S., and E. Kharroubi. 2015. "Why does financial sector growth crowd out real economic growth?" BIS Working Paper No. 490. Basel: Bank for International Settlements. Available at: www.bis.org/publ/work490.htm. 
Cerutti, E., S. Claessens, and P. McGuire. 2012. "Systemic Risks in Global Banking: What Can Available Data Tell Us and What More Data Are Needed?" BIS Working Paper No. 376. Basel: Bank for International Settlements. Available at: www.bis.org/publ/work376.pdf.

Chan-Lau, J.A. 2011. "Fat-Tails and Their (Un)Happy Endings: Correlation Bias and its Implications for Systemic Risk and Prudential Regulation.” IMF Working Paper No. 11/82. Washington, DC: International Monetary Fund. Available at: www.imf.org/external/pubs/ft/wp/2011/wp1182.pdf.

Ciocca, P. 2014. La banca che ci manca. Rome: Donzelli.

Committee of European Banking Supervisors (CEBS). 2010. "Guidelines for the joint assessment of the elements covered by the supervisory review and evaluation process (SREP) and the joint decision regarding the capital adequacy of cross border groups." CEBS Consultation Paper No. 39. London: Committee of European Banking Supervisors. Available at: www.eba.europa.eu/documents/10180/37070/CP39.pdf.

Corbisiero, G., and M. Musella. 1997. “Controllo dell'offerta di moneta. Stabilità del sistema finanziario ed equilibrio macroeconomico nell'analisi dei postkeynesiani: una critica alla distinzione tra accomodazionisti e strutturalisti." Studi e Note di Economia 1997(2): 129-47.

Crockett, A. 1997. "The Theory and Practice of Financial Stability." Essays in International Finance No. 203. Princeton, NJ: Princeton University. Available at: aulavirtual.bde.es/wav/documentos/area_docu_estabilidad_1.pdf.

Crotty, J. 2008. "Structural causes of the global financial crisis: a critical assessment of the "new financial architecture." UMASS Amherst Working Paper No. 14. Amherst, MA: University of Massachusetts Amherst, Department of Economics. Available at:

www.peri.umass.edu/fileadmin/pdf/conference_papers/SAFER/Crotty_Structural.p df

D'Amato, J.D.A., and C.H. Furfine. 2003. "Are credit ratings procyclical?” BIS Working Paper No. 129. Basel: Bank for International Settlements. Available at: www.bis.org/publ/work129.pdf.

Dabrowski, M. 2016. "Interaction between monetary policy and bank regulation: lessons for the ECB." CASE Networks Studies \& Analyses No. 480. Warsaw: Center for Social and Economic Research. Available at: http://www.caseresearch.eu/sites/default/files/publications/S\%26A\%20480.pdf.

Dante. 1920. Purgatorio, Canto 1, English translation by Courtney Langdon. London: Cambridge University Press. 
Degasperi, G. 1999. "La dinamica delle crisi finanziarie: i modelli di Minsky e Kindleberger." Alea-Università di Trento Tech Report No. 5. Trento: Università di Trento.

Demirguc-Kunt, A., and H. Huizinga. 2011. "Do we need big banks? Evidence on performance, strategy and market discipline." CEPR Discussion Paper No. 8276. Washington, DC: Center for Economic Policy and Research.

Diamond, D.W., and R.G. Rajan. 2001. "Liquidity Risk, Liquidity Creation, and Financial Fragility: A Theory of Banking." Journal of Political Economy 109(2): 287-327.

Dymski, G. 2010. "The Global Crisis and the Governance of Power in Finance." Mimeo. University of California. Available at: www.ie.ufrj.br/datacenterie/pdfs/seminarios/pesquisa/texto1008.pdf.

Dobbs, R., S. Lund, J. Woetzel, and M. Mutafchieva. 2015. "Debt and not much deleveraging." Report. London: McKinsey Global Institute. Available at: www.mckinsey.com/insights/economic_studies/debt_and_not_much_delevera ging/

Dombret, A., and O. Lucius. 2013. Stability of the Financial System. Illusion or Feasible Concept? Cheltenham, UK: Edward Elgar.

Drehmann, M., C. Borio, L. Gambacorta, G. Jimenez, and C. Trucharte. 2010. "Countercyclical capital buffers: exploring options." BIS Working Paper No. 317. Basel: Bank for International Settlements. Available at: www.bis.org/publ/work317.pdf.

Esposito, L. 2005. "I rischi e gli obiettivi della vigilanza finanziaria. Il caso della FSA inglese." Bancaria 2005(1): 79-88.

Esposito L. 2013. "Connect them where it hurts. The missing piece of the puzzle." Questioni di Economia e Finanza della Banca d'Italia 151. Rome: Banca d'Italia. Available at: www.bancaditalia.it/pubblicazioni/qef/20130151/QEF_151.pdf?language_id=1.

European Central Bank (ECB). 2010. Financial Stability Review, June. Frankfurt: European Central Bank. Available at: www.ecb.europa.eu/pub/pdf/other/financialstabilityreview201006en.pdf?e4a9882 9604731bb5628a660afla756c. 
European Commission (EC). 2009. "An EU Framework for Cross-Border Crisis

Management in the Banking Sector." Communication from the EC. Brussels:

European Commission. Available at:

ec.europa.eu/internal_market/bank/docs/crisis-

management/091020_communication_en.pdf.

European Commission (EC). 2014. "Economic Review of the Financial Regulation Agenda." Commission Staff Working Document. Brussels: European Commission. Available at: ec.europa.eu/internal_market/finances/docs/general/20140515-erfra-workingdocument_en.pdf.

Evanoff, D.D., D.S. Hoelscher, and G. Kaufmann. 2009. Globalization and Systemic Risk Systemic Risk and Prudential Regulation in the Global Economy. Singapore: World Scientific Publishing.

Financial Services Authority. 2009. "The Turner Review. A regulatory response to the global banking crisis." Official Report. London: Financial Services Authority. Available at: www.fsa.gov.uk/pubs/other/turner_review.pdf.

Financial Stability Board. 2010a. "Intensity and Effectiveness of SIFI Supervision Recommendations for Enhanced Supervision." Recommendations. Basel: Financial Stability Board. Available at: www.financialstabilityboard.org/wpcontent/uploads/r_101101.pdf?page_moved=1.

Financial Stability Board. 2010b. "Reducing the moral hazard posed by systemically important financial institutions." Recommendations. Basel: Financial Stability Board. Available at: www.financialstabilityboard.org/wpcontent/uploads/r_101111a.pdf?page_moved $=1$.

Financial Stability Board. 2011a. "Consultative Document Effective Resolution of Systemically Important Financial Institutions. Recommendations and Timelines." Recommendations. Basel: Financial Stability Board. Available at: www.cbrc.gov.cn/chinese/files/2011/20110818EF31DECC5BB3200BFFC2D9A 840A51E00.PDF.

Financial Stability Board. 2011b. "Policy Measures to Address Systemically Important Financial Institutions.” Recommendations. Basel: Financial Stability Board. Available at: www.financialstabilityboard.org/wpcontent/uploads/r_111104bb.pdf?page_moved=1.

Financial Stability Board. 2013. "Progress and Next Steps towards Ending 'Too-Big-ToFail' (TBTF)." Report of the Financial Stability Board to the G-20. Basel: Financial Stability Board. Available at: www.financialstabilityboard.org/wpcontent/uploads/r_130902.pdf. 
Fischer, S. 2014. "Financial Sector Reform: How Far Are We?” Martin Feldstein Lecture, July 10. Cambridge, MA: National Bureau of Economic Research. Available at: www.federalreserve.gov/newsevents/speech/fischer20140710a.htm.

Fisher, I. 1933. "The Debt-Deflation Theory of Great Depressions." Econometrica 1(4): $337-57$.

Fisher, R.W. 2013. Annual Report, Letter from the President. Federal Reserve Bank of Dallas. Available at: www.dallasfed.org/microsites/fed/annual/2012/ar12a/index.cfm.

Foley, D.F. 2010. "Hyman Minsky and the dilemmas of contemporary economic method." In R. Bellofiore and P. Ferri (eds.), Financial Keynesianism and Market Instability. Cheltenham, UK: Edward Elgar.

Fontana, G., and M. Sawyer. 2015. "Full Reserve Banking: More 'Cranks' than 'Brave Heretics." Mimeo. University of Leeds.

Fostel, A., and J. Geanakoplos. 2008. "Leverage Cycles and the Anxious Economy." Cowles Foundation Paper No. 1233. New Haven, CT: Cowles Foundation. Available at: dido.econ.yale.edu/ gean/art/p1233.pdf.

Freixas, X., and J.C. Rochet. 2008. Microeconomics of Banking. Cambridge, MA: The MIT Press.

French, K.R., M.N. Baily, J.Y. Campbell, J.H. Cochrane, D.W. Diamond, D. Duffie, A.K. Kashyap, F.S. Mishkin, R.G. Rajan, D.S. Scharfstein, R.J. Shiller, H.S. Shin, M.J. Slaughter, J.C. Stein, and R.M. Stulz. 2010. Squam Lake Report: Fixing the Financial System. Princeton, NJ: Princeton University Press.

Galati, G., and R. Moessner. 2011. "Macroprudential policy—a literature review." BIS Working Paper No. 337. Basel: Bank for International Settlements. Available at: www.bis.org/publ/work337.pdf.

Galbraith, J.K. 2001. The Essential Galbraith. Boston, MA: Houghton Mifflin Company.

Gambacorta, L., and A. Van Rixtel. 2013. "Structural bank regulation initiatives: approaches and implications." BIS Working Paper No 412. Basel: Bank for International Settlements. Available at: www.bis.org/publ/work412.pdf.

García-Palacios, H., A. Hasman, and M. Samartin. 2014. "Banking crises and government intervention." Journal of Financial Stability 15(12): 32-42. 
Goldstein, M., and N. Veron. 2011. Too Big To Fail: The Transatlantic Debate. Bruegel and the Peterson Institute for International Economics Working Paper No. 32011. Washington, DC: The Peterson Institute for International Economics. Available at: http://bruegel.org/wpcontent/uploads/imported/publications/Nicolas_Veron_WP_Too_big_to_fail_20 11_03.pdf.

Goodhart, C. 2010. "How should we regulate bank capital and financial products? What role for 'living wills'?" In A. Turner, A. Haldane, P. Woolley, S. Wadhwani, C. Goodhart, A. Smithers, A. Large, J. Kay, M. Wolf, P. Boone, and S. Johnson (eds.) The future of finance and the theory that underpins it. London: London School of Economics and Political Science.

Gordy, M.B., and B. Howells. 2006. "Procyclicality in Basel II: Can We Treat the Disease Without Killing the Patient?" Journal of Financial Intermediation 15(3): 395-417.

Greenspan, A. 2007. The Age of Turbulence. New York: Penguin Press.

Greider, W. 1987. Secrets of the Temple. New York: Simon \& Schuster.

Guttmann, R., and D. Plihon. 2010. "Consumer Debt and Financial Fragility." International Review of Applied Economics 24(3): 269-83.

Haldane, A.G. 2009a. "Banking on the State." BIS Review No. 139. Basel: Bank for International Settlements. Available at: www.bis.org/review/r091111e.pdf.

Haldane, A.G. 2009b. "Why banks failed the stress test." BIS Review No. 18. Basel: Bank for International Settlements. Available at: www.bis.org/review/r090219d.pdf.

Haldane, A.G. 2009c. "Rethinking the financial network." Speech at the Financial Student Association, Amsterdam, April 28. Available at: www.bankofengland.co.uk/archive/Documents/historicpubs/speeches/2009/speec h386.pdf.

Haldane, A.G. 2010. "The $\$ 100$ Billion Question." Comments given at the Institute of Regulation and Risk, Hong Kong, March 30. Available at: www.bankofengland.co.uk/archive/Documents/historicpubs/news/2010/036.pd $\mathrm{f}$

Haldane, A.G. 2012. "The Dog and the Frisbee." Speech given at the Federal Reserve Bank of Kansas City's 36th Economic Policy Symposium, "The Changing Policy Landscape," Jackson Hole, WY, August 31. Available at: www.bankofengland.co.uk/publications/Pages/speeches/2012/596.aspx. 
Haldane, A.G., S. Hall, and S. Pezzini. 2007. "A new approach to assessing risks to financial stability.” BoE Financial Stability Board No. 2. London: Bank of England. Available at:

http://www.bankofengland.co.uk/financialstability/Documents/fpc/fspapers/fs_p aper02.pdf.

Hawkins, J., and D. Mihaljek. 2001. "The banking industry in the emerging market economies: competition, consolidation and systemic stability." BIS Paper No. 4. Basel: Bank for International Settlements. Available at: www.bis.org/publ/bppdf/bispap04.pdf.

Hein, E. 2013. "Finance-dominated Capitalism and Redistribution of Income: A Kaleckian Perspective.” Levy Economics Institute Working Paper No. 746. Annandale-on-Hudson, NY: Levy Economics Institute of Bard College.

Hetzel, R.L. 1991. "Too Big to Fail: Origins, Consequences, and Outlook.” Federal Reserve Bank of Richmond Economic Review 77(6): 3-15.

Holmstrom, B., and J. Tirole. 1997. "Financial Intermediation, Loanable Funds, and the Real Sector." The Quarterly Journal of Economics 112(3): 663-91.

Huertas, T.F. 2015. “A resolvable bank.” In K. Scott and J. Taylor (eds.), Making Failure Feasible: How Bankruptcy Reform Can End Too Big to Fail. Stanford, CA: Stanford University Press.

Hughes, J.P., and L.J. Mester. 2011. "Who Said Large Banks Don’t Experience Scale Economies?" Federal Reserve Bank of Philadelphia Working Paper 11-27. Philadelphia: Federal Reserve Bank of Philadelphia. Available at: www.philadelphiafed.org/research-and-data/publications/workingpapers/2011/wp11-27.pdf.

International Monetary Fund (IMF). 2006. Global Financial Stability Report. Washington, DC: International Monetary Fund. Available at: www.imf.org/External/Pubs/FT/GFSR/2006/01/

International Monetary Fund (IMF). 2010. Global Financial Stability Report. Meeting New Challenges to Stability and Building a Safer System. Washington, DC: International Monetary Fund. Available at: www.imf.org/external/pubs/ft/gfsr/2010/01/pdf/text.pdf.

International Monetary Fund (IMF). 2011. World Economic Outlook, September. Washington, DC: International Monetary Fund. Available at: www.imf.org/external/pubs/ft/weo/2011/02/pdf/text.pdf. 
Jakab, Z., and M. Kumhof. 2015. "Banks are not intermediaries of loanable funds - and why this matters.” Bank of England Working Paper No. 529. London: Bank of England. Available at:

www.bankofengland.co.uk/research/Documents/workingpapers/2015/wp529.pdf.

Jaumotte, F., and C. Osorio Bruiton. 2015. "Inequality and Labor Market Institutions." IMF Discussion Note 15/14. Washington, DC: International Monetary Fund. Available at: www.imf.org/external/pubs/ft/sdn/2015/sdn1514.pdf.

Jiménez, G., J.A. Lopez, and J. Saurina. 2007. "How Does Competition Impact Bank Risk-Taking?" Federal Reserve Bank of San Francisco Working Paper 07-23. Available at: www.frbsf.org/publications/economics/papers/2007/wp07-23bk.pdf.

Johnson, S. 2009. “The Quite Coup.” The Atlantic. May. Available at: www.theatlantic.com/magazine/archive/2009/05/the-quiet-coup/307364/.

Johnson, S., and J. Kwak. 2010. 13 Bankers. The Wall Street Takeover and the Next Financial Meltdown. New York: Pantheon Books.

Kalecki, M. 1975. Selected Essays on the Dynamics of the Capitalistic Economy, 19331970. Cambridge, UK: Cambridge University Press.

Kambhu, J., S. Weidman, and N. Krishnan. 2007. “Concluding Observations.” In New Directions for Understanding Systemic Risk, Report on a Conference Cosponsored by the Federal Reserve Bank of New York and the National Academy of Sciences. Washington, DC: National Academies Press.

Kane, E.J. 1981. “Accelerating Inflation, Technological Innovation, and the Decreasing Effectiveness of Banking Regulation.” NBER Working Paper No. 638. Cambridge, MA: National Bureau of Economic Research. Available at: www.nber.org/papers/w0638.pdf.

Kashyap, A.K., and J.C. Stein. 2004. "Cyclical implications of the Basel II capital standards.” Federal Reserve of Chicago Economic Perspectives 1(2004): 18-31.

Kaufman, G.G. 2002. "Too big to fail in banking: What remains?" The Quarterly Review of Economics and Finance 42(3): 423-36.

Kay, J. 2009. "Narrow Banking: The Reform of Banking Regulation.” Mimeo. London: The Centre for the Study of Financial Innovation. Available at: www.johnkay.com/wp-content/uploads/2009/12/JK-Narrow-Banking.pdf.

Keen, S. 1995. "Finance and economic breakdown: modeling Minsky's 'financial instability hypothesis." Journal of Post Keynesian Economics 17(4): 607-35. 
Keynes, J.M. [1936] 1973. "The General Theory of Employment, Interest, and Money." In The Collected Writings, Vol. VII. London: MacMillan.

Kindleberger, C.P., and R.Z. Aliber. 2005. Manias, Panics and Crashes. London: MacMillan.

Kling, A. 2009. Not What They Had in Mind: A History of Policies that Produced the Financial Crisis of 2008. Arlington, VA: Mercatus Center, George Mason University. Available at: http://mercatus.org/sites/default/files/Kling-interiorweb.pdf.

Kohn, D.L. 2009. Comments on Hyun Song Shin paper "Financial intermediation and the post-crisis financial system." Eighth BIS Annual Conference, "Financial System and Macroeconomic Resilience," June 25-26, Basel. Available at: www.bis.org/publ/work304.pdf.

Korinek, A., and J. Kreamer. 2014. "The Redistributive Effects of Financial Deregulation: Wall Street versus Main Street.” BIS Working Paper No. 468. Basel: Bank for International Settlements. Available at: www.bis.org/publ/work468.pdf.

Kotlikoff, L.J. 2011. Jimmy Stewart Is Dead: Ending the World's Ongoing Financial Plague with Limited Purpose Banking. Hoboken, NJ: Wiley.

Kovacevich, R. 2014. "The Financial Crisis: Why the Conventional Wisdom Has It All Wrong." The Cato Journal 34(3): 541-56.

Kregel, J. 2010. "No Going Back: Why We Cannot Restore Glass-Steagall’s Segregation of Banking and Finance." Public Policy Brief No. 107. Annandale-on-Hudson, NY: Levy Economics Institute of Bard College

Kregel, J. 2012. “Using Minsky to Simplify Financial Regulation.” Research Project Report. Annandale-on-Hudson, NY: Levy Economics Institute of Bard College.

Kregel, J. 2014. "Minsky and Dynamic Macroprudential Regulation.” Public Policy Brief No. 131. Annandale-on-Hudson, NY: Levy Economics Institute of Bard College.

Kregel, J., and M. Tonveronachi. 2013. "Fundamental Principles of Financial Regulation and Supervision.” FESSUD Working Paper No. 29. Leeds: Financialisation, Economy, Society, and Sustainable Development. Available at: fessud.eu/wpcontent/uploads/2013/04/Fundamental-principles-of-financial-regulation-andsupervision-Working-paper-29.pdf.

Kumhof, M., R. Rancière, and P. Winant. 2015. "Inequality, Leverage, and Crises." American Economic Review 105(3): 1217-45. 
Laeven, L., L. Ratnovski, and H. Tong. 2014. "Bank Size and Systemic Risk." IMF Staff Discussion Note 1404. Washington, DC: International Monetary Fund. Available at: www.imf.org/external/pubs/ft/sdn/2014/sdn1404.pdf.

Lainà, P. 2015. "Money Creation under Full-reserve Banking: A Stock-flow Consistent Model." Levy Economics Institute Working Paper No. 851. Annandale-onHudson, NY: Levy Economics Institute of Bard College.

Lapavitsas, C. 2008. "Financialised Capitalism. Direct Exploitation and Periodic Bubbles." Mimeo. London: Department of Economics SOAS, University of London. Available at: www.leftlibrary.com/lapavitsas 1.pdf.

Lastra, R.M., and G. Wood. 2010. "The Crisis of 2007-09: Nature, Causes, and Reaction." Journal of International Economic Law 13(3): 531-50.

Loranth, G., and E. Sciubba. 2000. "Bank's Size, Risk and Competition.” Discussion Paper, Birkbeck College, University of London No. 24. London: University of London.

Marotta, G., and G.B. Pittaluga. 1993. La teoria degli intermediari bancari. Bologna: Il Mulino.

Masciandaro, D. 2012. "Monetary policy and banking supervision: still at arm's length? A comparative analysis." The European Journal of Comparative Economics 9(3): 349-66.

Masciandaro, D., R. Vega Pansini, and M. Quintyn. 2013. "The economic crisis: did supervision architecture and governance matter?" Journal of Financial Stability 9(4): 578-96.

McLeay, M., A. Radia, and R. Thomas. 2014. "Money creation in the modern economy." Bank of England Quarterly Bulletin, No. 1-2014. London: Bank of England. Available at: www.bankofengland.co.uk/publications/Documents/quarterlybulletin/2014/qb14q 1prereleasemoneycreation.pdf.

Merton, R.C. 1995. “A Functional Perspective of Financial Intermediation.” Financial Management 24(2): 23-41.

Miao, J., and P. Wang. 2014. "Sectoral bubbles, misallocation, and endogenous growth." Journal of Mathematical Economics 53(2014): 153-63.

Minsky, H.P. 1966. “Cash Flow Examination Procedures for Banks.” Memo. Hyman P. Minsky Archive, Paper No. 134. Available at: digitalcommons.bard.edu/hm_archive/134. 
Minsky, H.P. 1967. "Suggestions for a Cash Flow Oriented Bank Examination.” Memo. Hyman P. Minsky Archive, Paper No. 175. Available at: digitalcommons.bard.edu/hm_archive/175.

Minsky, H.P. 1975. "The Financial Instability Hypothesis: An Interpretation of Keynes and an Alternative to 'Standard Theory." Paper presented at the ASSA Convention, Dallas, TX. Hyman P. Minsky Archive, Paper No. 38. Available at: digitalcommons.bard.edu/hm_archive/38/.

Minsky, H.P. 1982a. “Can 'It' Happen Again? A Reprise.” Challenge July-August: 5-13. Hyman P. Minsky Archive, Paper No. 155. Available at: digitalcommons.bard.edu/hm_archive/155/.

Minsky, H.P. 1982b. Can “It” Happen Again? Essays on Instability and Finance. New York: M.E. Sharpe.

Minsky, H.P. 1986a. “Global Consequences of Financial Deregulation.” Wallenberg Forum, October 2. Hyman P. Minsky Archive, Paper 378. Available at: digitalcommons.bard.edu/hm_archive/378.

Minsky, H.P. 1986b. Stabilizing an Unstable Economy. New Haven, CT: Yale University Press.

Minsky, H.P. 1990. "Banking Reform and the Resumption of Sustained Growth." Hyman P. Minsky Archive, Paper No. 97. Available at: digitalcommons.bard.edu/hm_archive/97.

Minsky, H.P. 1992a. "Financial Instability and APT Bank Supervision.” Paper prepared for the 67th Annual WEA Conference, July 10, San Francisco. Hyman P. Minsky Archive, Paper 47. Available at: digitalcommons.bard.edu/hm_archive/470.

Minsky, H.P. 1992b. "Reconstituting the United States' Financial Structure: Some Fundamental Issues.” Levy Economics Institute Working Paper No. 69. Annandale-on-Hudson, NY: Levy Economics Institute of Bard College.

Minsky, H.P. 1994a. "Issues in Bank Regulation and Supervision.” Mimeo. Hyman P. Minsky Archive, Paper No. 72. Available at: digitalcommons.bard.edu/hm_archive/72.

Minsky, H.P. 1994b. "Regulation and Supervision." Mimeo. Hyman P. Minsky Archive, Paper No. 443. Available at: digitalcommons.bard.edu/hm_archive/443.

Minsky, H.P. 1995. "Reforming Banking in 1995: Repeal of the Glass Steagall Act, Some Basic Issues.” Mimeo. Hyman P. Minsky Archive, Paper No. 59. Available at: digitalcommons.bard.edu/hm_archive/59. 
Minsky, H.P. 1996. "Uncertainty and the Institutional Structure of Capitalist Economies." Levy Economics Institute Working Paper No. 155. Annandale-on-Hudson, NY: Levy Economics Institute of Bard College.

Minsky, H.P., and G. Campbell. 1988. "Getting off the Back of a Tiger: The Deposit Insurance Crisis in the United States." Washington University Working Paper No. 121. St. Louis, MO: Washington University. Hyman P. Minsky Archive, Paper No. 67. Available at: digitalcommons.bard.edu/hm_archive/67.

Minsky, H.P., D.B. Papadimitriou, R.J. Phillips., and L.R. Wray. 1993. "Community Development Banking: A Proposal to Establish a Nationwide System of Community Development Banks." Levy Economics Institute Public Policy Brief No. 3. Annandale-on-Hudson, NY: Levy Economics Institute of Bard College.

Mishkin, F.S. 2002. Prudential Supervision. What works and what doesn't. Chicago, IL: The University of Chicago Press.

Moosa, I.A. 2010. The Myth of Too Big to Fail. London: Palgrave MacMillan.

Nakamoto, M., and D. Wighton. 2007. "Citigroup chief stays bullish on buy-outs." Financial Times, July 9.

Nersisyan, Y. 2015. "The Repeal of the Glass-Steagall Act and the Federal Reserve's Extraordinary Intervention during the Global Financial Crisis." Levy Economics Institute Working Paper No. 829. Annandale-on-Hudson, NY: Levy Economics Institute of Bard College.

Onado, M. 2012. Economia e regolamentazione del sistema finanziario. Bologna: Il Mulino.

Organisation for Economic Co-operation and Development (OECD). 2014. "Does income inequality hurt economic growth?" Focus on Inequality and Growth, December. Paris: Organisation for Economic Co-operation and Development. Available at: www.oecd.org/els/soc/Focus-Inequality-and-Growth-2014.pdf.

Ötker-Robe, I., C. Pazarbasioglu, A. Buffa di Perrero, S. Iorgova, T. Kışınbay, V. Le Leslé, F. Melo, J. Podpiera, N. Sacasa, and A. Santos. 2010. "Impact of Regulatory Reforms on Large and Complex Financial Institutions." IMF Staff Position Note No. 16. Washington, DC: International Monetary Fund. Available at: www.imf.org/external/pubs/ft/spn/2010/spn1016.pdf.

Ötker-Robe, I., A. Narain, and A. Ilyina. 2011. "The Too-Important-to-Fail Conundrum: Impossible to Ignore and Difficult to Resolve.” IMF Staff Discussion Note No. 12. Washington, DC: International Monetary Fund. Available at: http://www.imf.org/external/pubs/ft/sdn/2011/sdn1112.pdf. 
Palley, T.I. 2007. "Financialization: What It Is and Why It Matters." Levy Economics Institute Working Paper 525. Annandale-on-Hudson, NY: Levy Economics Institute of Bard College.

Panico, C., A. Pinto, and M. Puchet Anyul. 2012. "Income distribution and the size of the financial sector: a Sraffian analysis." Cambridge Journal of Economics 36(6): $1455-77$.

Panitch, L. 2009. "Rebuilding Banking." Red Pepper blog, January. Available at: http://www.redpepper.org.uk/Rebuilding-Banking.

Pare, T.P. 1995. “Today's hot concept, tomorrow's forest fire.” Fortune, May 15.

Parker, R.E. 2007. The Economics of the Great Depression. Northampton, MA: Edward Elgar.

Passarella, M. 2012. "A simplified stock-flow consistent dynamic model of the systemic financial fragility in the 'New Capitalism.'” Journal of Economic Behavior \& Organization 83(3): 570-82.

Persaud, A.D. 2000. "Sending the herd off the cliff edge: the disturbing interaction between herding and market-sensitive risk management practices." BIS Papers No. 2. Basel: Bank for International Settlements. Available at: www.bis.org/publ/bppdf/bispap021.pdf.

Philippon, T. 2008. "The Evolution of the US Financial Industry from 1860 to 2007: Theory and Evidence." Mimeo. Stanford University. Available at: economics.stanford.edu/files/Philippon5_20.pdf.

Polouček, S. 2014. "Lender of last resort and too-big-to-fail hypothesis." Mimeo. VŠB-Technical University of Ostrava Faculty of Economics, Department of Economics. Available at: icfb.rs.opf.slu.cz/sites/icfb.rs.opf.slu.cz/files/37_poloucek.pdf.

Powell, J.H. 2013. "Ending 'too big to fail." Speech at the Institute of International Bankers Washington Conference, Washington, DC, March 4. Available at: www.bis.org/review/r130305b.pdf.

Pozen, R. 2010. Too Big to Save? How to Fix the U.S. Financial System. Hoboken, NJ: Wiley.

Radde, S. 2012. "Liquidity Crises, Banking, and the Great Recession." German Economic Association, Annual Conference, Gottingen, September 9-12. Available at: econstor.eu/bitstream/10419/65408/1/VfS_2012_pid_528.pdf. 
Rajan, R.G. 2005. "Has Financial Development Made the World Riskier?” NBER Working Paper No. 11728. Cambridge, MA: National Bureau of Economic Research. Available at: www.nber.org/papers/w11728.

Rajan, R.G. 2010. Fault Lines, How Hidden Fractures Still Threaten the World Economy. Princeton, NJ: Princeton University Press.

Repullo, R., and J. Suarez. 2008. “The Procyclical Effects of Basel II.” Paper presented at the 9th Jacques Polak Annual Research Conference Hosted by the IMF, Washington, DC, November 13-14. Available at: www.imf.org/external/np/res/seminars/2008/arc/pdf/rs.pdf.

Rosenblum, H. 2011. "Choosing the Road to Prosperity Why We Must End Too Big to Fail—Now." Annual Report. Dallas: Federal Reserve Bank of Dallas. Available at: www.dallasfed.org/assets/documents/fed/annual/2011/ar11.pdf.

Roubini, N., and S. Mihm. 2010. Crisis Economic. London: Allen Lane.

Ryoo, S. 2013. "Bank Profitability, Leverage and Financial Instability." Cambridge Journal of Economics 37(5): 1127-60.

Sawyer, M. 2015. “The scourge of green monetarism.” Mimeo. Leeds: University of Leeds.

Scherer, F.M. 2010. "A perplexed economist confronts 'too big to fail."” The European Journal of Comparative Economics 7(2): 267-84.

Shiller, R. 2009. Rational Exuberance. Princeton, NJ: Princeton University Press.

Shull, B. 2010. "Too Big to Fail in Financial Crisis: Motives, Countermeasures, and Prospects." Levy Economics Institute Working Paper No. 601. Annandale-onHudson, NY: Levy Economics Institute of Bard College.

Siegert, C., and M. Willison. 2015. "Estimating the extent of the 'too big to fail' problem - a review of existing approaches." Bank of England Financial Stability Paper No. 32. London: Bank of England. Available at: www.bankofengland.co.uk/financialstability/Documents/fpc/fspapers/fs_paper32. pdf.

Singh, A. 2013. "Too Big to Fail Bank: Examining the How of Breaking Up." Mimeo. Cambridge, MA: Harvard University. Available at: www.law.harvard.edu/programs/about/pifs/education/llm/2012---2013/aditisingh-final-paper.pdf. 
Skott, P. 2012. "Pluralism, the Lucas critique, and the integration of macro and micro." University of Massachusetts Working Paper No. 2012-04. Amherst, MA: University of Massachusetts Amherst. Available at: http://www.umass.edu/economics/publications/2012-04.pdf.

Smith, A. 2007 [1776]. An Inquiry into the Nature and Causes of the Wealth of Nations. Petersfield, UK: Harriman House Ltd.

Sorkin, A.R. 2009. Too Big to Fail. Inside the Battle to Save Wall Street. London: Allen Lane.

Stephens, P. 2011. "Vickers hands victory to the bankers' shop steward." Financial Times, September 13.

Stiglitz, J.E. 2009. "Too big to fail or too big to save? Examining the systemic threats of large financial institutions." Hearing before the Joint Economic Committee Congress of the United States of America of the One Hundred Eleventh Congress, First Session, April 21. Available at: www.gpo.gov/fdsys/pkg/CHRG-111shrg52189/pdf/CHRG-111shrg52189.pdf.

Stiglitz, J.E. 2010. Freefall. New York: Norton.

Stiroh, K.J., and P.E. Strahan. 2003. "Competitive Dynamics of Deregulation: Evidence from U.S. Banking." Journal of Money, Credit \& Banking 35(5): 801-28.

Strange, S. 1996. Mad Money: When markets outgrow governments. Ann Arbor, MI: The University of Michigan Press.

Summers, D. 2008. "No return to boom and bust: what Brown said when he was Chancellor." The Guardian, September 11.

Tarashev, N., C. Borio, and K. Tsatsaronis. 2010. "Attributing systemic risk to individual institutions." BIS Working Paper No. 308. Basel: Bank for International Settlements. Available at: www.bis.org/publ/work308.pdf.

Taylor, A., and C.A.E. Goodhart. 2004. "Procyclicality and volatility in the financial system: The implementation of Basel II and IAS 39." Mimeo. London: London School of Economics and Political Science. Available at: www.hkimr.org/uploads/conference_detail/803/con_paper_0_135_charlesgoodhart.pdf.

Temin, P. 1989. Lessons from the Great Depression. Cambridge, MA: MIT Press.

Thakor, A.V. 2010. "Financial crises and the challenges for future research." Bancaria Special Issue No. 3-2010: 11-15.

The Economist. 2013. "Twilight of the gods.” May 11. 
Tonveronachi, M. 2009. "Distorsioni strutturali della regolamentazione prudenziale delle banche." Moneta e Credito 55(217): 3-17.

Toporowski, J. 2000. The end of finance: The theory of capital market inflation, financial derivatives and pension fund capitalism. London: Routledge.

Toporowski, J. 2010. Why the World Economy Needs a Financial Crash and Other Critical Essays on Finance and Financial Economics. London: Anthem Press.

Travaglini, G. 2009. "Le diseguaglianze alla radice del crack." Blog post. Available at: http://www.sbilanciamoci.info/content/pdf/1677.

Triana, P. 2009. Lecturing Birds on Flying. Can Mathematical Theories Destroy the Financial Markets? Hoboken, NJ: Wiley.

Tufano, P. 2002. "Financial Innovation.” Mimeo. Cambridge, MA: Harvard Business School. Available at:

www.econ.chula.ac.th/public/members/sothitorn/Financial_inovetion_5G.pdf.

Turner, A. 2012. Economics after the Crisis. Objectives and Means. Cambridge, MA: MIT Press.

Turner, A. 2015. "The Micro and the Macro: Risk management and financial instability." Tommaso Padoa-Schioppa Memorial Lecture London, June 18. Available at: www.ifrs.org/Features/Documents/PadoaSchioppa\%20Lecture\%20June\%202015.pdf.

Turner, A., A. Haldane, P. Woolley, S. Wadhwani, C. Goodhart, A. Smithers, A. Large, J. Kay, M. Wolf, P. Boone, and S. Johnson. 2010. The future of finance and the theory that underpins it. London: London School of Economics and Political Science.

Van Roy, P. 2008. "Capital Requirements and Bank Behavior in the Early 1990s: CrossCountry Evidence.” International Journal of Central Banking 4(3): 29-60.

van Treeck, T. 2013. "Did Inequality Cause the U.S. Financial Crisis?" IMK Working Paper No. 91-2012. Düsseldorf: Macroeconomic Policy Institute (IMK) of the Hans-Böckler-Foundation. Available at: www.boeckler.de/pdf/p_imk_wp_91_2012.pdf.

Varoufakis, I. 2013. "Global Banks as Exporters of Permanent Credit Crunches to Peripheral Economies: The case of Mexico.” Blog post, September 5. Available at: http://yanisvaroufakis.eu/2013/09/05/global-banks-as-exporters-ofpermanent-credit-crunches-to-peripheral-economies-the-case-of-mexico/. 
Vickers, J. 2012. "Some Economics on Banking Reform.” University of Oxford Discussion Paper No. 632. Oxford: University of Oxford. Available at: www.economics.ox.ac.uk/materials/papers/12467/paper632.pdf.

Voltaire. 1817. Oeuvres Complètes, Tome Septieme. Paris: Th. Desoer.

Wagner, W. 2010. "In the Quest of Systemic Externalities: A Review of the Literature." CESifo Economic Studies 56(1): 96-111.

Wheelock, D.C., and P.W. Wilson. 2012. "Do Large Banks Have Lower Costs? New Estimates of Returns to Scale for US Banks." Journal of Money, Credit \& Banking 44(1): 171-99.

Wilkinson, R., and K. Pickett. 2009. The Spirit Level. New York: Bloomsbury Press.

Wolfe, M. 2009, "Why the Turner report is a watershed for finance." Financial Times, March 19.

Wray R.L. 2011a. "Lessons We Should Have Learned from the Global Financial Crisis but Didn't." Levy Economics Institute Working Paper No. 681. Annandale-on-Hudson, NY: Levy Economics Institute of Bard College.

Wray, R.L. 2011b. “A Minskyan Road to Financial Reform.” Levy Economics Institute Working Paper No. 655. Annandale-on-Hudson, NY: Levy Economics Institute of Bard College.

Wray, R.L. 2011c. "Minsky's Money Manager Capitalism and the Global Financial Crisis." Levy Economics Institute Working Paper No. 661. Annandale-onHudson, NY: Levy Economics Institute of Bard College.

Wray, L.R. 2015. "Minsky on Banking: Early Work on Endogenous Money and the Prudent Banker." Levy Economics Institute Working Paper No. 827. Annandaleon-Hudson, NY: Levy Economics Institute of Bard College.

Yellen, J.L. 1996. "Remarks at the Conference on Recent Developments in the Financial System." Levy Economics Institute, Annandale-on-Hudson, NY, April, 11. 


\section{APPENDIX 1: BANKING SUPERVISION MEASURES AFTER THE CRISIS}

Here we analyze the main banking supervision initiatives undertaken after the crisis. ${ }^{16}$ We divide them into three areas: prudential supervision, structural measures, and compliance and other measures.

\section{A1. PRUDENTIAL SUPERVISION}

In a nutshell, capital requirements have been made higher and stronger (that is, of higher quality). This is the core message of Basel III. Other important aspects are: the return of non-risk-based requirements (the leverage ratio), a serious consideration of the liquidity risk, and specific measures for big banks (so called SIFISs or G-SIBs).

As far as the first aspect is concerned, risk-based ratios were deemed better before the crisis, as "normal" ratios were prone to arbitrage. The problem is that risk-based ratios were even easier to bypass using overly optimistic internal models, so the leverage ratio of the banks exploded. The victory of risk-based supervision also meant a drastic reduction in liquid assets (see, for instance, BOE [2010]). These trends increased micro profitability but also macro financial fragility. The return of a leverage ratio and liquidity ratios is a strong reminder of how much the crisis changed the landscape. For instance, liquidity risk in Basel II is barely mentioned. Now it is paramount again.

As for the SIFIs, it has finally been acknowledged that size matters in finance and they are different in many ways (Esposito 2013). Therefore, as far as prudential supervision is concerned, the Financial Stability Board (FSB) and the Basel Committee on Banking Supervision (BSBC) proposed additional capital requirements for more systemically important banks (see the documents of the FSB in the bibliography).

All in all, these steps go in the right direction and one that is also envisaged in the

\footnotetext{
${ }^{16}$ For a recent analysis, see Basel Committee (2015).
} 
Minskyan framework, as we have seen. The issue is that capital ratios are rarely a cause of concern until the collapse of the bank. For instance, just before its demise, Lehman Brothers had a tier 1 ratio higher than the minimum required by Basel III (Johnson and Kwak 2010). More generally, "none of the largest 100 banks were constrained by de jure capital standards in the period 1982-2000" (Taylor and Goodhart 2004) and the "IMF has shown that all of the banks that required bailouts in the crisis reported higher-thanaverage levels of capital in the last period before the intervention" (Calomiris and Herring [2013]; on the issue see also Allen and Carletti [2009]; Caprio [2013]; Avgouleas [2015]). Kay (2009) concludes:

\footnotetext{
These rules proved worse than useless. Banks entered the crisis with capital generally in excess of the regulatory requirements. These provisions proved not just inadequate, but massively inadequate, for the problems they faced.
}

Finally, we should also observe that in the originate-to-distribute (OTD) model, capital ratios are not relevant, as the banks do not hold the assets on their books (Wray 2011b). If capital ratios are not a direct useful indicator of a bank's state of health, what is their role? They can be seen as a discipline mechanism: by respecting regulatory ratios, a bank demonstrates it is healthy and is considered healthy by the market. In other words, it is the beauty contest all over again. Only in this sense of peer discipline are capital ratios a way to distinguish healthy from unhealthy banks.

Therefore, all these measures, although positive, are unlikely to make a substantial difference (especially for big banks); however the renewed importance placed on liquidity risk has been a welcome development.

\section{A2. STRUCTURAL MEASURES}

Before the crisis, structural supervision was definitely out of fashion. The demise of the Glass-Steagall Act in 1999 confirmed it. This was due to many causes, the main ones being deregulation and globalization. Prudential supervision is easy to apply to different 
business models, systems, and firms. Whatever they are and whatever they do, banks must have a given capital/assets ratio. On the contrary, structural measures are eminently national and model specific so they are very difficult to apply on an international scale. The return of structural supervision is then an indication of the impasse faced by international banking (see Esposito [2013: sec. 3.3]; Ötker-Robe et al. [2011]).

The essence of structural supervision is that the law directly allows or forbids specific activities and organizational structures. This is how the Volcker rule or the British ringfencing work. These measures can rapidly change the way banks work, but they have also a number of drawbacks. Some of the objections are not very relevant. For instance, the ECB (2010) is against the Volcker rule because it would run counter to the established model of universal banking and might trigger unintended effects, such as the migration of riskier activities to less-regulated (and often less capitalized) areas of the financial system. What happened before the crisis shows that life without the Volcker rule was not so good after all. However, the crisis was not confined to securities trading:

Would a Glass-Steagall Act work? Not really. Think of Northern Rock. Of HBOS [Halifax Bank of Scotland]. Indeed of our Greek banks. They contained no substantial investment arms, no casino banking. And yet they were the ones that failed. (Kovacevich 2014)

Moreover, the securities section of the balance sheet is now linked to the others, as Kregel (2010) observes:

A return to Glass-Steagall thus presents a conundrum. Since the activities that currently provide the least costly method of short-term business financing are fundamentally linked to securities market activities, they would be prohibited to regulated banks. In addition, it would appear impossible to legislate monopoly protections similar to those of 1933 for deposits without active monitoring and prohibiting competitive innovations by nonregulated institutions.

It is also likely that these measures would help big banks to create business models that are more and more similar, thus reducing the diversity of the financial system, as well as contributing to a fragmentation of banking markets along national lines (the latter consequence is not unanimously considered negatively) (Moosa 2010). 
It is worth noting that Minsky proposed something similar to ring fencing in 1995 (Kregel 2012) as a way to go on without the Glass-Steagall Act; mainstream scholars reached his conclusions two decades later, when the situation is by far more serious and this measure alone can hardly make a significant difference.

Facing the failure of light-touch supervision, many commentators proposed ways besides the Volcker rule to punish banks for their nontraditional activities. For instance, Fisher (2013) proposed confining access to the federal safety net (the Fed's discount window and federal deposit insurance protection) to traditional commercial banks (see also Rajan [2010]). Others proposed so-called narrow banking, which is basically a proposal to separate insured deposit-taking from lending activities, or even more extreme proposals such as Kotlikoff's (2011) limited-purpose banking.

The main drawback of these measures is that they would prevent banks from creating liquidity, which is one of their fundamental contributions to the economy (Diamond and Rajan 2001). As Kregel (2012) put it: "It is the level of business investment and government net expenditures that generate the cash flow that validates the corporate liabilities and produces the real source of financial stability in the system." Moreover, they might exacerbate price and, hence, market instability (Turner et al. 2010; Sawyer 2015). By eliminating the creation of liquidity, they would create a permanent trend towards deflation and a credit crunch, also reducing the possibility of banks acting as the Schumpeterian handmaiden to innovation and creative destruction (Kregel 2014). ${ }^{17}$ Additionally, there might not be enough government bonds to back retail deposits, especially of short- to medium-term maturity, or their allocation could be seriously affected because their "natural holders," such as pension funds, would find them in short supply (Vickers 2012). Finally, narrow banking would destroy bank profitability, so it would be politically unfeasible (Wray 2015).

\footnotetext{
${ }^{17}$ Lainà (2015) uses a stock-flow consistent model to show the opposite.
} 


\section{A3. COMPLIANCE AND OTHER MEASURES}

We deal here with a long series of heterogeneous measures. We will only touch on the most relevant for this work.

The first and more debated is the creation of an effective way to close a bank. The resolution of big banks has been a nightmare because of their size, interconnectedness, and international reach. As these features are considered good or not modifiable, a lot of work has been done on resolution mechanisms to build "a framework to resolve failed financial institutions in a way that minimizes disruption to the financial system when failure occurs" (Ötker-Robe et al. 2011). Concretely, many ideas have been put forward, such as "living wills," bail-ins, and contingent capital (European Commission 2009; Acharya et al. 2010; FSB 2011a; IMF 2010; Chan-Lau 2011; Powell 2013; and Huertas 2015). In Europe, we have seen the creation of the single resolution mechanism. ${ }^{18}$

The idea behind these measures is correct and can be synthetized as follows: "It is imperative to reinstate a credible fear of bankruptcy for banks and other systemically significant financial institutions so as to ensure that banks once more play their proper role in a market economy" (Lastra and Wood 2010). The question is: Do resolution mechanisms worry the CEOs of big banks, forcing them to change their business model? Hardly so. The second point is that "in front of an imminent crisis, the promise of no interventions made by governments is barely credible" (García-Palacios et al. 2014). In other words, all these mechanism are prone to the time inconsistency issue. Thirdly, they are ex post measures and in general they are not able to prevent a crisis. Finally, these measures constitute an implicit subsidy to big banks because the bail-in process will favor the migration of deposits and other liabilities from small to large banks. For all these drawbacks, they are nonetheless important in a different way, already envisaged long ago by Minsky (1986b) who talked of an "easy and cheap" way to resolve a bank. The question is uncertainty and credibility. These measures can convince the markets that the situation is more stable and under control, helping to improve the situation. Once

\footnotetext{
${ }^{18} \mathrm{http}: / /$ ec.europa.eu/finance/general-policy/banking-union/single-resolution-mechanism/index_en.htm.
} 
again, a beauty contest.

A second aspect is the return of systemic risk and macroprudential tools. This is a very important development and it is not by chance that before the crisis the macro dimension of supervision was nonexistent - it was the practical consequence of microfoundations in economic theory. Just like mainstream economics does not have a place for nonmicrofounded phenomena, Basel II does not have a place for macroprudential supervision. Now the situation has changed so much that specific authorities have been created to study systemic risk, like the European Systemic Risk Board (ESRB) in Europe and the Office of Financial Research (OFR) in the US. Needless to say, systemic risk means SIFIs. In fact, deepening systemic risk means deepening the different risks posed by big banks to the world economy (see Haldane [2010], Blanchard et al. [2010], and Ötker-Robe et al. [2010] for a thorough analysis of measures to reduce systemic risk posed by the SIFIs).

A related item is the quest for better data and better accounting practices. Authorities and investors have complained about the lack of data with which to judge the true situation of the banks during the crisis. Moreover, international accounting standards (in particular the fair-value method) have been exposed as procyclical. For instance, Brunnermeier et al. (2009) proposed substituting the mark-to-market method with a mark-to-funding one. This is a good idea. However, we should observe that just like the "true model" of the economy does not exist because we live in a beauty contest world, the fair value of an asset or a liability is linked to the overall situation of the financial market. Risks affect prices, but also the other way around - there is no an exogenous anchor for balance-sheet values (Borio and Tsatsaronis 2005). This is the problem with the so-called "early warnings." They can predict when a bank is in a bad situation but cannot do the same for a system, so there are limits on how much we can do with new data (Crockett 1997).

A different set of measures is linked to business conduct and consumer protection. The end of the bubble is always a period of frauds and swindles (chapter IX of Kindleberger and Aliber [2005] is dedicated to analyzing the fraud epidemic at the end of a bubble; see 
also Fisher [1933]). ${ }^{19}$ The last crisis was no exception. As banks were saved to the tune of trillions dollars of public money, their business conduct was under the public scrutiny. Out-of-court settlements and fines of tens of billions of dollars have been fairly common ${ }^{20}$ and there have been many measures concerning this topic, such as creating special alternative dispute resolutions (ADRs), specific supervision tools, and so on, and specific authorities (like the US Consumer Financial Protection Bureau [CFPB] and the British Financial Conduct Authority [FCA]) have been created. This trend was linked to the political backlash against the banks (think, for instance, of the "we are the 99\%" movement in the US). However, the strictness of enforcement of this regulation is likely to be extended to banking supervision as a whole, ${ }^{21}$ because during the bubble no one is interested in quarrelling with the banks.

Another line of action has been education. As authorities are not confident in the possibility of changing the banks' behavior, they try to change their clients' instead. This is the idea behind financial education programs set up to help people understand financial products. ${ }^{22}$ The problem is that it is simplistic to believe that people behave in a given way because they don't know better. Do the CEOs of big banks understand financial markets? Of course they do, and yet they cannot help but inflate a bubble until they end up crushed under it. As for normal people, many times they simply do not have choice. For instance, many observe that their savings are too low to ensure a decent retirement income. Is it poorly designed pension funds regulation? Is it financial illiteracy? Are taxes on savings too high or are wages simply too low? The issue behind the financial choices of consumers is income distribution - the lower the wages, the higher the debts. No financial education program can change this basic fact. The same is true for pension adequateness. In 1992, Minsky observed that the "financial unsophistication of a vast proportion of the population is becoming evident" due to the privatization of the pension

\footnotetext{
${ }^{19}$ Even Marx has a say on the topic: "On the other hand, there appears swindling and a general promotion of swindling by recourse to frenzied ventures with new methods of production, new investments of capital, new adventures, all for the sake of securing a shred of extra profit which is independent of the general average and rises above it." See: http://www.marxists.org/archive/marx/works/cw/volume37/index.htm.

${ }^{20}$ For the US experience, see: http://blogs.reuters.com/data-dive/2014/08/22/bank-of-americas-big-fine/ and for the UK: http://www.economist.com/news/finance-and-economics/21642200-another-ruinous-talesharp-practice-may-be-reaching-close-43.

${ }^{21} \mathrm{http} / / / \mathrm{www} \cdot$ reuters.com/investigates/special-report/usa-bankrules-weakening/.

${ }^{22} \mathrm{http}: / / \mathrm{www}$. oecd.org/finance/financial-education/.
} 
system.

The last kind of interventions we touch on can be labelled "skin-in-the-game incentives." The idea is to punish short-termism and behaviors that are too risky (for instance, with a Minskyan perspective, Wray [2011b]). This is nothing new (see, for instance, Kregel [2014]). No one can deny that something has to change in this respect given that, as we already noted, in 2008 Wall Street paid bonuses in excess of $\$ 18$ billion after being saved by US taxpayers. The question is: Is that reckless behavior part of the beauty contest and of the overall trajectory of the bubble? Additionally, since the size of a CEO's compensation package is linked to the size of the firm, reducing the latter will necessarily reduce the former. 


\section{APPENDIX 2: FROM HOW MANY TO HOW MANY?}

Our proposal is aimed at eliminating the too-big-to-fail (TBTF) banks issue for ever. We can ask how much the compulsory break up would affect present SIFIs, namely how many over-the-threshold banks exist right now and how many would exist after the application of the global cap? According to Global Finance, at the end of 2014, the biggest 50 banks in the world had combined total assets of around $\$ 69$ trillion, ${ }^{23}$ roughly $90 \%$ of the world GDP. Applying a cap at $\$ 300$ billion, they would be separated into more than 230 banks, a radical reduction in concentration. In the same year in EU there were 25 banks with more than $€ 300$ billion in total assets and more than $€ 21$ trillion total assets when all 25 are taken together. After the split there would be more than 70 . In the US the number would grow from 7 to $25 .{ }^{24}$

If we consider the TBTF banks as a separate market and calculate the HerfindahlHirschman Index for them, we find that for EU the index would be reduced from around 520 to 142 , and in the US from almost 2,000 to 400. Again, the scale of deconcentration would be without precedent. This would mean reducing Sisyphus's rock into very small pieces.

\footnotetext{
${ }^{23}$ Data source: https://www.gfmag.com/magazine/november-2015/biggest-global-banks-2015. For the sake of simplicity, we use a cap of 300 billion (euro or dollar) with no conversion.

${ }^{24}$ Data source for the EU: http://europe.deposits.org/biggest-banks.html; data source for the US http://www.federalreserve.gov/Releases/Lbr/current/default.htm.
} 